\title{
Novel Foveavirus (the family Betaflexiviridae) species identified in ginseng (Panax ginseng)
}

\author{
D. PARK ${ }^{1}$, M. ZHANG ${ }^{2}$, Y. HAHN ${ }^{1 *}$
}

\begin{abstract}
${ }^{1}$ Department of Life Science, Chung-Ang University, 84 Heukseok-ro, Dongjak-gu, Seoul 06974, South Korea; ${ }^{2}$ College of Life Science, Jilin Agricultural University, Changchun 130118, Jilin, P. R. China
\end{abstract}

Received July 17, 2018; accepted August 7, 2018

\begin{abstract}
Summary. - Ginseng (Panax ginseng) is a valuable herb that is widely cultivated in Korea, China, and Japan because it contains a variety of pharmacologically active substances with a wide range of positive effects on human health. Identification and prevention of disease-causing viral pathogens of ginseng is important for improving the yield and quality of ginseng-derived bioactive molecules. In this study, the genome sequence of the virus Panax ginseng flexivirus 1 (PgFV1) was identified from a ginseng root transcriptome data set. Sequence comparison and phylogenetic analysis showed that PgFV1 is a novel plant RNA virus species of the genus Foveavirus (the family Betaflexiviridae). Foveaviruses have flexuous and filamentous virions with a single-stranded positivesense mono-segmented RNA genome. Its infection causes diseases with mosaic and ringspot symptoms in the stems and leaves. The PgFV1 genome encodes for 5 open reading frames: a replicase polyprotein for viral genome replication, 3 triple gene block proteins for viral cell-to-cell movement, and coat protein. Phylogenetic trees inferred from replicase polyprotein or coat protein sequences showed that PgFV1 is most closely related to grapevine virus T. PgFV1 is the first foveavirus identified to be associated with ginseng. Given the potential pathogenic features of previously known foveaviruses and importance of ginseng in the health industry, the PgFV1 genome sequence may be highly useful for studying ginseng foveaviruses.
\end{abstract}

Keywords: ginseng; Panax ginseng flexivirus 1; Foveavirus; Betaflexiviridae

\section{Introduction}

Ginseng (Panax ginseng) is a slowly growing perennial plant belonging to the genus Panax of the family Araliaceae, which is widely cultivated in Korea, China, and Japan. Ginseng has long been used as a valuable herb in oriental medicine because it contains various pharmacologically active substances such as ginsenosides (dammarane-type tri-

*Corresponding author. E-mail: hahny@cau.ac.kr; phone: +82-2820-5812.

Abbreviations: ASPV = apple stem pitting virus; $\mathrm{CP}=$ coat protein; $\mathrm{GRSPaV}=$ grapevine rupestris stem pitting-associated virus; $\mathrm{GVT}=$ grapevine virus $\mathrm{T}$; $\mathrm{ORF}=$ open reading frame; PgFV1 = Panax ginseng flexivirus $1 ;$ PVM = potato virus $M$; $\mathrm{REP}=$ replicase polyprotein; $\mathrm{RdRp}=\mathrm{RNA}$-dependent RNA polymerase; sgRNA = subgenomic RNA; SRA = Sequence Read Archive; $\mathrm{TGB}=$ triple gene block terpenoid saponins) and gintonin (Briskin, 2000; Yun, 2001; Baeg and So, 2013). Ginseng is known to have a wide range of positive effects on human health including preventing some types of cancers, improving diabetes and vascular diseases, enhancing host immunity, and protecting against some virus infections (Vuksan et al., 2010; Kim and Park, 2011; Im et al., 2016). Several comprehensive transcriptomic analyses using next-generation sequencing technology have been performed to understand the underlying molecular genetic mechanisms of the beneficial traits of ginseng (Jayakodi et al., 2015; Wang et al., 2015; Zhen et al., 2015; Jo et al., 2017a; Xu et al., 2017; Zhang et al., 2017).

Identification of pathogens that cause disease in ginseng is important for improving the quality and yield of ginsengderived substances. For example, fungal pathogens, such as Cylindrocarpon destructans and Fusarium solani, cause root rot of ginseng and lead to yield losses (Ohh, 1981; Jang et al., 2010). Several viruses, such as a Closterovirus species (the 
family Closteroviridae) and watermelon mosaic virus (the genus Potyvirus, the family Potyviridae), have been identified to infect or be associated with ginseng (Mishchenko et al., 2009; Jung et al., 2013; Park et al., 2017).

Application of next-generation sequencing methods has been demonstrated to be a rapid, efficient, and inexpensive method for the detection and characterization of viral sequences (Barba et al., 2014). When transcriptomic analyses of plant samples are performed, genome sequences of plant RNA viruses present in the sample may be isolated together with host RNA molecules. Thus, RNA virus genome sequences can be found in plant transcriptome data deposited in publicly available databases such as the Sequence Read Archive (SRA) or Transcriptome Shotgun Assembly databases of the National Center for Biotechnology Information (NCBI) (Liu et al., 2012; Jo et al., 2017b). In this study, a ginseng transcriptome dataset was analyzed to identify RNA viruses that potentially infect ginseng (Wang et al., 2015). As a result, a genome sequence of a novel Foveavirus species was found and annotated.

\section{Materials and Methods}

RNA-seq assembly. A previously published ginseng transcriptome data set (SRA accession number SRP066368) was analyzed (Wang et al., 2015). The data set contained approximately 26.5 gigabases of paired-end reads obtained from 18 RNA samples, which were prepared from various tissues of ginseng at different ages. High-quality sequences were collected by filtering raw RNA-seq reads using the sickle program (version 1.33; https://github.com/ najoshi/sickle) with the option "-q 30 -1 55." The SPAdes Genome Assembler (version 3.10.1; http://spades.bioinf.spbau.ru) with the “--rna” option was used for de novo assembly of RNA-seq reads (Bankevich et al., 2012). Eighteen transcriptome data sets were separately assembled into contigs.

Detection of virus-derived contigs. All RNA sequence contigs were analyzed to detect potentially virus-derived contigs containing a viral RNA-dependent RNA polymerase (RdRp) motif. The reference sequences of viral RdRps were prepared from the Pfam database (release 31.0; http://pfam.xfam.org). Pfam accession numbers for viral RdRp motifs were PF00602, PF00603, PF00604, PF00680, PF00946, PF00972, PF00978, PF00998, PF02123, PF03431, PF04196, PF04197, PF05788, PF05919, PF07925, PF08467, PF08716, PF08717, and PF12426. A total of 394 nonredundant viral RdRp motif sequences were collected and converted into a custom-built BLAST-searchable database. BLASTX searches were performed against RdRp motif sequences using assembled contigs as queries with the parameter "-evalue e-5." Mapping of RNA-seq reads to a viral genome contig was carried out using BWA program (version 0.7.16a-r1181; https://github.com/lh3/bwa) with the "mem" method (Li and Durbin, 2009). Sequence variants were analysed using SAMtools/BCFtools programs (version 1.6; http:// www.htslib.org) (Li et al., 2009).

Multiple sequence alignments. The NCBI BLAST (https://blast. ncbi.nlm.nih.gov/Blast.cgi) searches were performed to identify and collect closely related viruses. Open reading frames (ORFs) were predicted based on BLASTX searches and ORF finder analysis (https://www.ncbi.nlm.nih.gov/orffinder). Functional domains of viral proteins were identified by using Pfam and TMHMM (version 2.0; http://www.cbs.dtu.dk/services/TMHMM) (Sonnhammer et al., 1998). Pair-wise identities among protein sequences were calculated using the FASTA program (version 36.3.6; https://fasta. bioch.virginia.edu/fasta_www2/fasta_down.shtml).

Multiple alignments of protein sequences were generated using MUSCLE software (version 3.8.425; https://www.drive5.com/ muscle) (Edgar, 2004). A phylogenetic relationship among viruses was inferred using the neighbor-joining method implemented in the ClustalW2 program (version 2.1; http://www.clustal.org) (Larkin et al., 2007).

\section{Results and Discussion}

A 9002 nucleotide (nt) long contig isolated from a 12 -year old ginseng root sample (SRA accession number SRR2952882) showed amino acid (aa) sequence similarity with the RdRp motif sequence of apple stem pitting virus (ASPV) (UniProt Acc. No., Q64962; Pfam Acc. No., PF00978). ASPV is the type species of the genus Foveavirus of the family Betaflexiviridae (Jelkmann, 1994), suggesting that the putative viral contig was derived from a foveavirus or related virus.

A BLASTX search against the non-redundant protein database using the NCBI BLAST confirmed that the putative viral contig was related to foveaviruses, including grapevine virus T (GVT) (Jo et al., 2017b) and grapevine rupestris stem pitting-associated virus (GRSPaV) (Meng et al., 1998). The contig was considered a novel ginseng RNA virus of the genus Foveavirus of the family Betaflexiviridae and named as Panax ginseng flexivirus 1 (PgFV1). The PgFV1 genome sequence with annotation information is available in the NCBI nucleotide database under Acc. No. MH036372.

The ginseng root RNA-seq reads (SRA Acc. No., SRR2952882) were mapped to the PgFV1 genome contig. A total of 22,513 reads were mapped to the PgFV1 genome. There were only two single-nucleotide polymorphism sites at nt positions 52 and 55, indicating that the PgFV1 genome contig was assembled from a highly homogeneous viral population. The two single-nucleotide polymorphism sites were in the 5 -untranslated region of the virus genome.

Viruses in the genus Foveavirus (the family Betaflexiviridae) have flexuous and filamentous virions with a singlestranded positive-sense mono-segmented RNA genome 
Table 1. ORFs and functional domains of PgFV1

\begin{tabular}{|c|c|c|c|c|c|c|}
\hline Protein & nt position & nt length & aa length & Domain & Pfam & aa position \\
\hline \multirow[t]{4}{*}{ Replicase polyprotein (REP) } & $57-6476$ & 6420 & 2139 & Viral methyltransferase & PF01660 & 43-354 \\
\hline & & & & Carlavirus endopeptidase & PF05379 & $1163-1250$ \\
\hline & & & & Viral (superfamily 1) RNA helicase & PF01443 & 1334-1599 \\
\hline & & & & RNA-dependent RNA polymerase & PF00978 & $1711-2130$ \\
\hline Triple gene block protein 1 (TGB1) & $6559-7224$ & 666 & 221 & Viral (superfamily 1) RNA helicase & PF01443 & $24-221$ \\
\hline \multirow[t]{3}{*}{ Triple gene block protein 2 (TGB2) } & $7228-7575$ & 348 & 115 & Plant viral movement protein & PF01307 & $4-107$ \\
\hline & & & & Transmembrane & & $12-29$ \\
\hline & & & & Transmembrane & & $71-93$ \\
\hline \multirow[t]{2}{*}{ Triple gene block protein 3 (TGB3) } & $7502-7738$ & 237 & 78 & $7 \mathrm{kDa}$ viral coat protein & PF02495 & $2-63$ \\
\hline & & & & Transmembrane & & $7-26$ \\
\hline Coat protein $(\mathrm{CP})$ & $7755-8633$ & 879 & 292 & Viral coat protein & PF00286 & $110-247$ \\
\hline
\end{tabular}

of approximately 8.4-9.3 kb (Martelli and Jelkmann, 1998; Martelli et al., 2007). The natural hosts of foveaviruses include dicotyledonous woody plants such as grapevines, apple trees, peach trees, or apricot trees (Jelkmann, 1994; Meng et al., 1998; James et al., 2007; Youssef et al., 2011). In many cases, foveavirus infection causes diseases manifested as mottle, mosaic, and ringspot symptoms in the stems and leaves. Foveaviruses are transmitted via grafting and no biological vectors have been reported.

The PgFV1 genome sequence was predicted to contain 5 ORFs (Table 1 and Fig. 1, top), which are commonly shared with other foveaviruses (Jelkmann, 1994; Martelli and Jelkmann, 1998; Martelli et al., 2007). ORF1, which is the longest ORF, encodes a 2139 aa long replicase polyprotein (REP). REP was predicted to contain 4 known domains: a viral methyltransferase, carlavirus endopeptidase, viral RNA helicase, and RdRp.

The next 3 ORFs (ORF2, ORF3, and ORF4) encode for triple gene block protein 1 (TGB1), triple gene block protein 2 (TGB2), and triple gene block protein 3 (TGB3), respectively, which constitute tripartite movement proteins involved in the cell-to-cell movement of viruses (Kalinina et al., 2002; Rebelo et al., 2008). The sizes of these proteins are 221, 115, and 78 aa, respectively. TGB1 contains a viral RNA helicase domain, which shows approximately $17.5 \%$ aa sequence identity with the viral RNA helicase domain of REP. The two RNA helicase domains belong to the same Pfam domain family PF01443. TGB2 has a plant viral movement protein domain and TGB3 has a $7 \mathrm{kDa}$ viral coat protein domain. Transmembrane domain prediction using the TMHMM showed that the TGB2 and TGB3 proteins contain 2 and 1 transmembrane domains, respectively. The presence of transmembrane domains in these proteins agrees with a previous report showing that these two proteins are membrane-associated and are essential for viral mobilization (Rebelo et al., 2008).
ORF5 encodes a 292 aa long coat protein (CP). CP contains a viral coat protein domain that is shared with coat proteins of other Betaflexiviridae viruses such as members of the genera Potexvirus and Carlavirus (Rupasov et al., 1989; Querci et al., 1993).

ORF1 (REP) of the family Betaflexiviridae is directly translated from genomic RNA. In contrast, the other ORFs are translated from subgenomic RNAs (sgRNAs), which were transcribed from genomic RNA (Martelli et al., 2007). It is thought that foveaviruses generate two sgRNAs, one for the 3 TGB proteins and another for the $\mathrm{CP}$, although their presence in the plant cells has not been confirmed (Fig. 1, arrows). When RNA-seq reads isolated from the ginseng root sample (SRR2952882) were analyzed, a total of 22,513 reads were found to be derived from PgFV1. Interestingly, the sequencing depth plot of the PgFV1 genome showed an elevated sequencing depth at the 3 ' region, which approximately coincides with putative sgRNA segments (Fig. 1, graph). The observed read depth elevation suggests the presence of sgRNAs in ginseng cells. However, it is also possible that the pattern resulted from biased cDNA synthesis because of a local RNA structure or the experimental procedure employed.

For phylogenetic analysis of PgFV1, a BLAST search against the NCBI protein database was performed using the PgFV1 genome sequence as a query. A total of 11 related viral genomes were collected, including GVT, GRSPaV, peach chlorotic mottle virus (PCMV), apricot latent virus (ApLV), ASPV, apple green crinkle associated virus (AGCaV), rubus canadensis virus 1 (RuCV1), Asian prunus virus 1 (APV1), Asian prunus virus 2 (APV2), Asian prunus virus 3 (APV3), and potato virus $\mathrm{M}(\mathrm{PVM})$. The first 10 viruses are members of the genus Foveavirus. PVM, the type species of the most closely related genus Carlavirus, was included as an outgroup (Rupasov et al., 1989).

Protein sequence identities between PgFV1 proteins and their respective orthologs of related viruses were calculated 


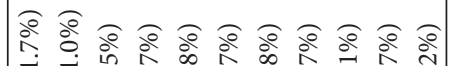

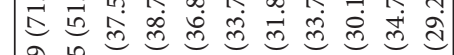

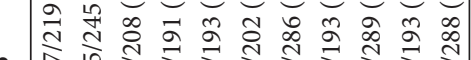

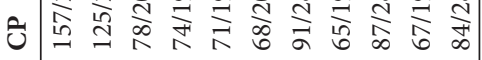

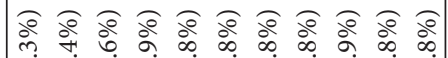
Ұु तु क्ल

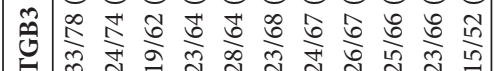

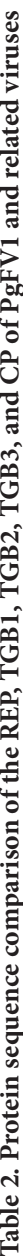

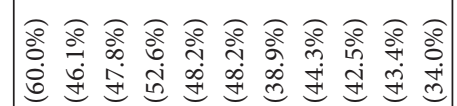
드는

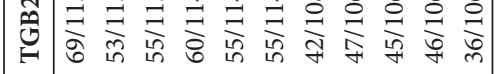

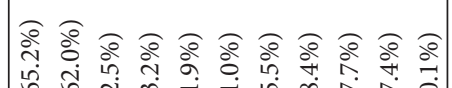

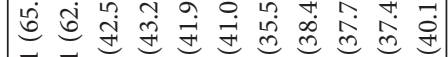

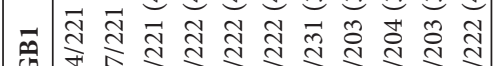

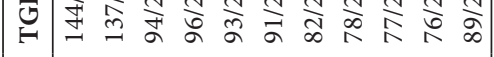

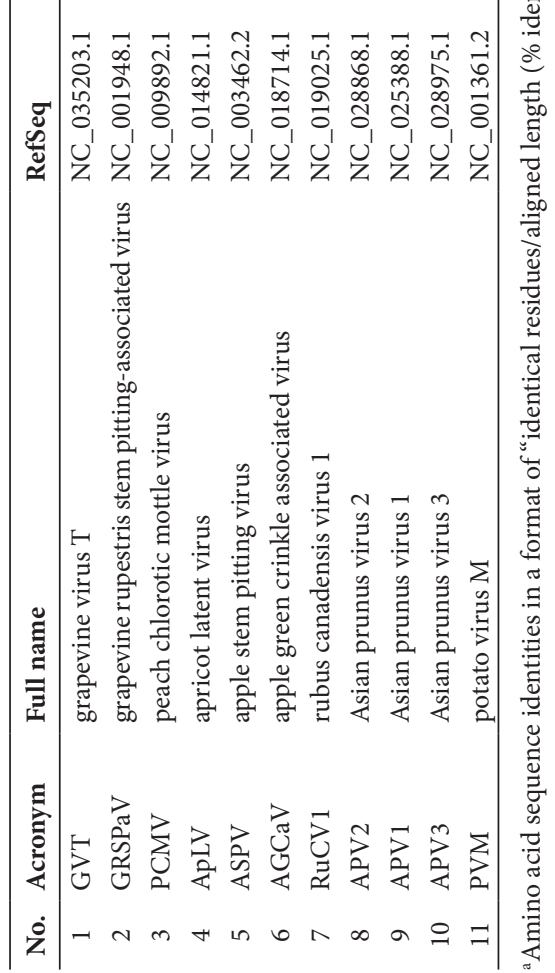
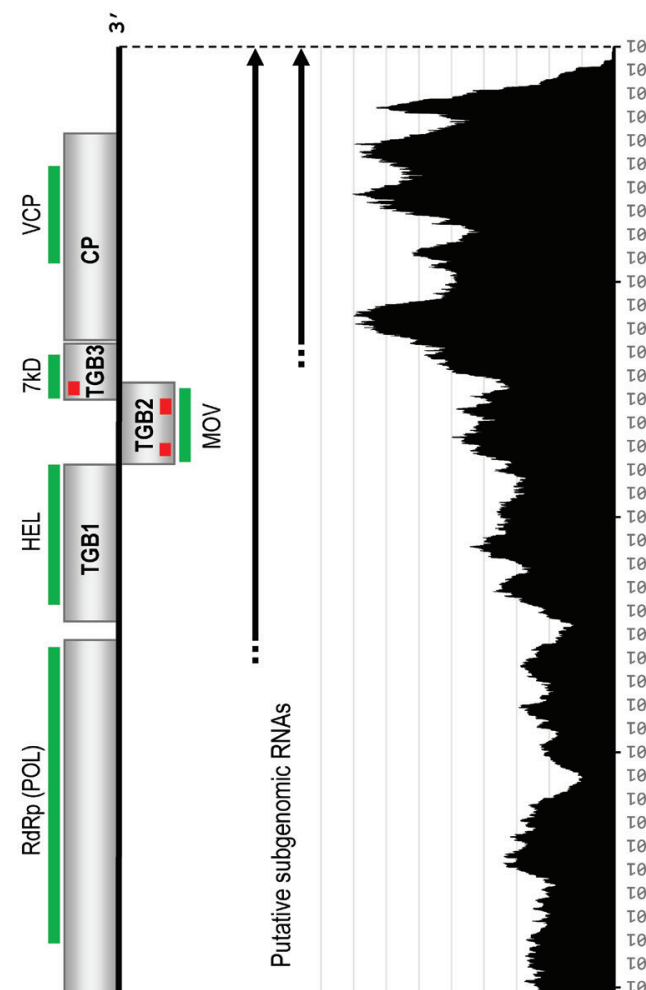

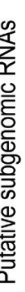

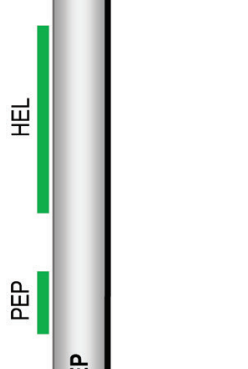

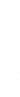

㝵

을 चै

寻留

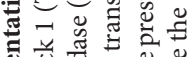

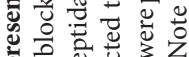

휜

㟧范范券

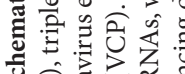

战荥已合

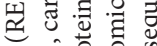

昰舁苦总

运节

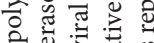

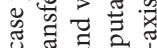

产苍苞

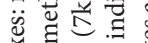

雪贯

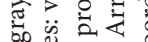

品寻范

प्ष

,

官司总

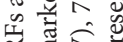

ठี

คิ

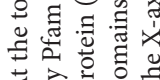




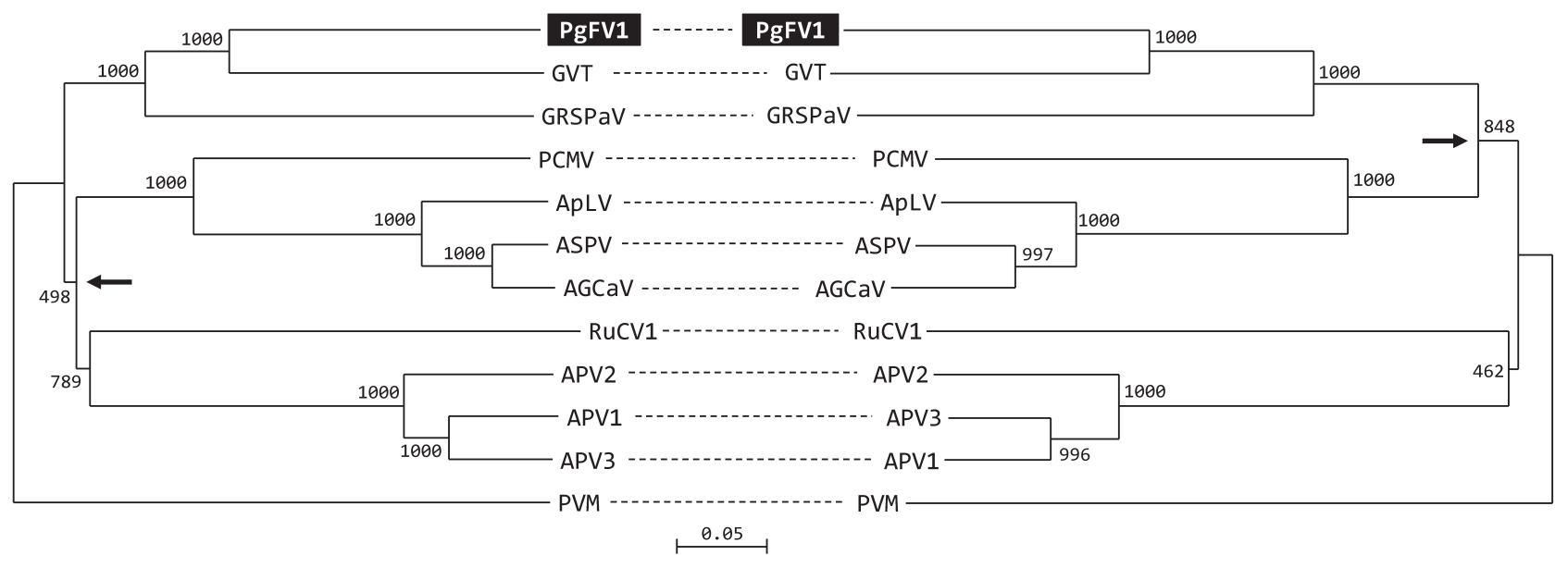

Fig. 2

Phylogenetic tree of PgFV1 and related viruses

Phylogenetic trees were inferred from multiple alignments of REP (left) and CP (right) sequences. Trees were rooted using sequences of PVM, the type species of the genus Carlavirus. The node showing a topology discrepancy between two trees is marked by an arrow in each tree. The bootstrap values obtained from 1000 replicates are shown at the nodes. Full names and accession numbers of viruses are presented in Table 2.

(Table 2). The highest aa sequence identity of the PgFV1 REP was found with the GVT REP (59.7\% identity over 2147 aa overlap) and the second highest with the GRSPaV REP (52.8\% identity over 2170 aa overlap). REP proteins of the remaining viruses showed lower identities (37-45\%) with the PgFV1 REP.

The other PgFV1 proteins (TGB1, TGB2, TGB3, and CP) also showed the highest identities with respective proteins of GVT, indicating that GVT is the most closely related known virus to PgFV1. The sequence identity between the PgFV1 CP and GVT CP was $71.7 \%$ over 219 aa overlap. The CP or REP protein sequence identity threshold for assigning foveaviruses to different species is approximately $80 \%$ (Adams et al., 2004), confirming that PgFV1 is a novel species.

Multiple sequence alignment of PgFV1 proteins with the respective orthologs of 10 other foveaviruses and 1 carlavirus revealed conserved regions mainly corresponding to known functional domains (Supplementary Figs. 1-5). Phylogenetic trees inferred from REP and CP sequences confirmed that PgFV1 is a member of the genus Foveavirus and formed a subclade with GVT and GRSPaV (Fig. 2). Phylogenetic tree topologies from two proteins were nearly the same except for a difference of the sister clade from the PgFV1/GVT/ GRSPaV subclade. The tree inferred from REP sequences showed that PgFV1, GVT, and GRSPaV formed a sister clade of all other foveaviruses (Fig. 2 left). However, the tree from CP showed that the PgFV1/GVT/GRSPaV subclade was a sister clade of the PCMV/ApLV/ASPV/AGCaV subclade (Fig. 2 right). This discrepancy may be related to ancestral recombination events which have been reported for several foveaviruses (Komorowska et al., 2011; Glasa et al., 2017).
In conclusion, the genome sequence of PgFV1, a novel member of the genus Foveavirus of the family Betaflexiviridae, was identified from a ginseng root transcriptome data set. Sequence comparison and phylogenetic analysis indicated that PgFV1 is most closely related to GVT. PgFV1 is thought to be the first foveavirus found to be associated with ginseng although no disease symptoms have been confirmed. Given the important status of ginseng in the health industry and tendency of foveaviruses to cause diseases, further studies of PgFV1 and other foveaviruses potentially associated with ginseng are needed. The genome sequence of PgFV1 reported in this report may be useful for investigating ginseng foveaviruses.

Acknowledgments. This research was supported by the Chung-Ang University Graduate Research Scholarship in 2017.

Supplementary information is available in the online version of the paper.

\section{References}

Adams MJ, Antoniw JF, Bar-Joseph M, Brunt AA, Candresse T, Foster GD, Martelli GP, Milne RG, Zavriev SK, Fauquet CM (2004): The new plant virus family Flexiviridae and assessment of molecular criteria for species demarcation. Arch. Virol. 149, 1045-1060. https://doi.org/10.1007/ s00705-004-0304-0

Baeg IH, So SH (2013): The world ginseng market and the ginseng (Korea). J. Ginseng Res. 37, 1-7. https://doi.org/10.5142/ jgr.2013.37.1 
Bankevich A, Nurk S, Antipov D, Gurevich AA, Dvorkin M, Kulikov AS, Lesin VM, Nikolenko SI, Pham S, Prjibelski AD, Pyshkin AV, Sirotkin AV, Vyahhi N, Tesler G, Alekseyev MA, Pevzner PA (2012): SPAdes: a new genome assembly algorithm and its applications to single-cell sequencing. J. Comput. Biol. 19, 455-477. https://doi.org/10.1089/ cmb.2012.0021

Barba M, Czosnek H, Hadidi A (2014): Historical perspective, development and applications of next-generation sequencing in plant virology. Viruses 6, 106-136. https:// doi.org/10.3390/v6010106

Briskin DP (2000): Medicinal plants and phytomedicines. Linking plant biochemistry and physiology to human health. Plant Physiol. 124, 507-514. https://doi.org/10.1104/ pp.124.2.507

Edgar RC (2004): MUSCLE: multiple sequence alignment with high accuracy and high throughput. Nucleic Acids Res. 32, 1792-1797. https://doi.org/10.1093/nar/gkh340

Glasa M, Predajna L, Soltys K, Sihelska N, Nagyova A, Wetzel T, Sabanadzovic S (2017): Analysis of Grapevine rupestris stem pitting-associated virus in Slovakia reveals differences in intra-host population diversity and naturally occurring recombination events. Plant Pathol. J. 33, 34-42. https:// doi.org/10.5423/PPJ.OA.07.2016.0158

Im K, Kim J, Min H (2016): Ginseng, the natural effectual antiviral: Protective effects of Korean red ginseng against viral infection. J. Ginseng Res. 40, 309-314. https://doi. org/10.1016/j.jgr.2015.09.002

James D, Varga A, Croft H (2007): Analysis of the complete genome of peach chlorotic mottle virus: identification of non-AUG start codons, in vitro coat protein expression, and elucidation of serological cross-reactions. Arch. Virol. 152, 2207-2215. https://doi.org/10.1007/s00705007-1050-X

Jang CS, Lim JH, Seo MW, Song JY, Kim HG (2010): Direct detection of Cylindrocarpon destructans, root rot pathogen of ginseng by nested PCR from soil samples. Mycobiology 38, 33-38. https://doi.org/10.4489/MYCO.2010.38.1.033

Jayakodi M, Lee SC, Lee YS, Park HS, Kim NH, Jang W, Lee HO, Joh HJ, Yang TJ (2015): Comprehensive analysis of Panax ginseng root transcriptomes. BMC Plant Biol. 15, 138. https://doi.org/10.1186/s12870-015-0527-0

Jelkmann W (1994): Nucleotide sequences of apple stem pitting virus and of the coat protein gene of a similar virus from pear associated with vein yellows disease and their relationship with potex- and carlaviruses. J. Gen. Virol. 75, 1535-1542. https://doi.org/10.1099/0022-1317-75$\underline{7-1535}$

Jo IH, Lee J, Hong CE, Lee DJ, Bae W, Park SG, Ahn YJ, Kim YC, Kim JU, Lee JW, Hyun DY, Rhee SK, Hong CP, Bang KH, Ryu H (2017a): Isoform sequencing provides a more comprehensive view of the Panax ginseng transcriptome. Genes (Basel) 8. https://doi.org/10.3390/genes8090228

Jo Y, Song MK, Choi H, Park JS, Lee JW, Lian S, Lee BC, Cho WK (2017b): Genome sequence of Grapevine virus T, a novel foveavirus infecting grapevine. Genome Announc. 5. https://doi.org/10.1128/genomeA.00995-17
Jung W-K, Nam M, Lee JH, Park CY, Kim BH, Park EH, Lee M-A, Kim M-K, Choi H-S, Lee JS, Kim J-S, Choi JK, Kwon TR, Lee K-W, Lee S-H (2013): Novel pathogenic strain of Watermelon mosaic virus occurred on insam (Panax ginseng). Res. Plant Dis. 19, 331-337. https://doi. org/10.5423/RPD.2013.19.4.331

Kalinina NO, Rakitina DV, Solovyev AG, Schiemannc J, Morozov SY (2002): RNA helicase activity of the plant virus movement proteins encoded by the first gene of the triple gene block. Virology 296, 321-329. https://doi.org/10.1006/ viro.2001.1328

Kim SK, Park JH (2011): Trends in ginseng research in 2010. J. Ginseng Res. 35, 389-398. https://doi.org/10.5142/ jgr.2011.35.4.389

Komorowska B, Siedlecki P, Kaczanowski S, Hasiow-Jaroszewska B, Malinowski T (2011): Sequence diversity and potential recombination events in the coat protein gene of Apple stem pitting virus. Virus Res. 158, 263-267. https://doi. org/10.1016/j.virusres.2011.03.003

Larkin MA, Blackshields G, Brown NP, Chenna R, McGettigan PA, McWilliam H, Valentin F, Wallace IM, Wilm A, Lopez R, Thompson JD, Gibson TJ, Higgins DG (2007): Clustal W and Clustal X version 2.0. Bioinformatics 23, 2947-2948. https://doi.org/10.1093/bioinformatics/btm 404

Li H, Durbin R (2009): Fast and accurate short read alignment with Burrows-Wheeler transform. Bioinformatics 25, 1754 1760. https://doi.org/10.1093/bioinformatics/btp324

Li H, Handsaker B, Wysoker A, Fennell T, Ruan J, Homer N, Marth G, Abecasis G, Durbin R, 1000 Genome Project Data Processing Subgroup (2009): The Sequence Alignment/Map format and SAMtools. Bioinformatics 25, 2078-2079. https://doi.org/10.1093/bioinformatics/btp352

Liu H, Fu Y, Xie J, Cheng J, Ghabrial SA, Li G, Yi X, Jiang D (2012): Discovery of novel dsRNA viral sequences by in silico cloning and implications for viral diversity, host range and evolution. PLoS One 7, e42147. https://doi.org/10.1371/ journal.pone.0042147

Martelli GP, Adams MJ, Kreuze JF, Dolja VV (2007): Family Flexiviridae: a case study in virion and genome plasticity. Annu. Rev. Phytopathol. 45, 73-100. https://doi. org/10.1146/annurev.phyto.45.062806.094401

Martelli GP, Jelkmann W (1998): Foveavirus, a new plant virus genus. Arch. Virol. 143, 1245-1249. https://doi.org/10.1007/ $\underline{\text { s007050050372 }}$

Meng B, Pang SZ, Forsline PL, McFerson JR, Gonsalves D (1998): Nucleotide sequence and genome structure of grapevine rupestris stem pitting associated virus- 1 reveal similarities to apple stem pitting virus. J. Gen. Virol. 79 ( Pt 8), 2059 2069. https://doi.org/10.1099/0022-1317-79-8-2059

Mishchenko LT, Korenieva AA, Molchanets OV, Boiko AL (2009): Detection of viral infection pathogens in medicinal plants grown in Ukraine. Mikrobiol. Z 71, 55-61.

Ohh SH (1981): Diseases of ginseng: Environmental and host effect on disease outbreak and growth of pathogens. J. Ginseng Res. 5, 73-84.

Park D, Kim H, Hahn Y (2017): Genome sequence of a distinct watermelon mosaic virus identified from ginseng (Panax 
ginseng) transcriptome. Acta Virol. 61, 479-482. https:// doi.org/10.4149/av $2017 \quad 410$

Querci M, van der Vlugt R, Goldbach R, Salazar LF (1993): RNA sequence of potato virus X strain HB. J. Gen. Virol. 74 ( Pt 10), 2251-2255. https://doi.org/10.1099/0022-131774-10-2251

Rebelo AR, Niewiadomski S, Prosser SW, Krell P, Meng B (2008): Subcellular localization of the triple gene block proteins encoded by a foveavirus infecting grapevines. Virus Res. 138, 57-69. https://doi.org/10.1016/j.virusres.2008.08.011

Rupasov VV, Morozov S, Kanyuka KV, Zavriev SK (1989): Partial nucleotide sequence of potato virus M RNA shows similarities to protexviruses in gene arrangement and the encoded amino acid sequences. J. Gen. Virol. 70 ( Pt 7), 1861-1869. https://doi.org/10.1099/0022-1317$\underline{70-7-1861}$

Sonnhammer EL, von Heijne G, Krogh A (1998): A hidden Markov model for predicting transmembrane helices in protein sequences. Proc. Int. Conf. Intell. Syst. Mol. Biol. 6, 175-182.

Vuksan V, Sievenpipper J, Jovanovski E, Jenkins AL (2010): Current clinical evidence for Korean red ginseng in management of diabetes and vascular disease: A Toronto's ginseng clinical testing program. J. Ginseng Res. 34, 264-273. https:// doi.org/10.5142/jgr.2010.34.4.264

Wang K, Jiang S, Sun C, Lin Y, Yin R, Wang Y, Zhang M (2015): The spatial and temporal transcriptomic landscapes of ginseng, Panax ginseng C. A. Meyer. Sci. Rep. 5, 18283. https://doi.org/10.1038/srep18283
Xu J, Chu Y, Liao B, Xiao S, Yin Q, Bai R, Su H, Dong L, Li X, Qian J, Zhang J, Zhang Y, Zhang X, Wu M, Zhang J, Li G, Zhang L, Chang Z, Zhang Y, Jia Z, Liu Z, Afreh D, Nahurira R, Zhang L, Cheng R, Zhu Y, Zhu G, Rao W, Zhou C, Qiao L, Huang Z, Cheng YC, Chen S (2017): Panax ginseng genome examination for ginsenoside biosynthesis. Gigascience 6, 1-15. https://doi.org/10.1093/gigascience/ gix093

Youssef F, Marais A, Faure C, Barone M, Gentit P, Candresse T (2011): Characterization of Prunus-infecting apricot latent virus-like foveaviruses: evolutionary and taxonomic implications. Virus Res. 155, 440-445. https://doi. org/10.1016/j.virusres.2010.11.013

Yun TK (2001): Brief introduction of Panax ginseng C. A. Meyer. J. Korean Med. Sci. 16 (Suppl.), S3-5. https://doi. org $/ 10.3346 / \mathrm{jkms} .2001 .16 . S . S 3$

Zhang JJ, Su H, Zhang L, Liao BS, Xiao SM, Dong LL, Hu ZG, Wang P, Li XW, Huang ZH, Gao ZM, Zhang LJ, Shen L, Cheng RY, Xu J, Chen SL (2017): Comprehensive characterization for ginsenosides biosynthesis in ginseng root by integration analysis of chemical and transcriptome. Molecules 22. https://doi.org/10.3390/molecules22060889

Zhen G, Zhang L, Du Y, Yu R, Liu X, Cao F, Chang Q, Deng X, Xia M, He H (2015): De novo assembly and comparative analysis of root transcriptomes from different varieties of Panax ginseng C. A. Meyer grown in different environments. Sci. China Life Sci. 58, 1099-1110. https://doi. org/10.1007/s11427-015-4961-X 


\title{
Supplementary information
}

\section{Novel Foveavirus (family Betaflexiviridae) species identified in ginseng (Panax ginseng)}

\author{
D. PARK ${ }^{1}$, M. ZHANG ${ }^{2}$, Y. HAHN ${ }^{1 *}$
}

${ }^{1}$ Department of Life Science, Chung-Ang University, 84 Heukseok-ro, Dongjak-gu, Seoul 06974, South Korea;

${ }^{2}$ College of Life Science, Jilin Agricultural University, Changchun 130118, Jilin, P. R. China 


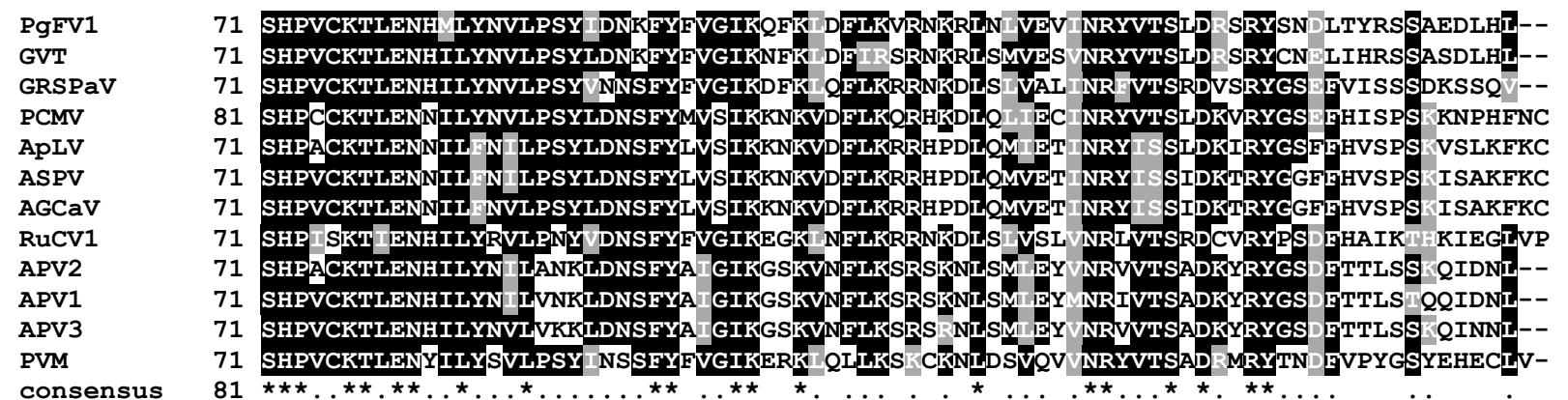

PgFV1

GVT

GRSPaV

PCMV

ApLV

ASPV

AGCaV

RuCV1

APV2

APV1

APV3

PVM

consensus

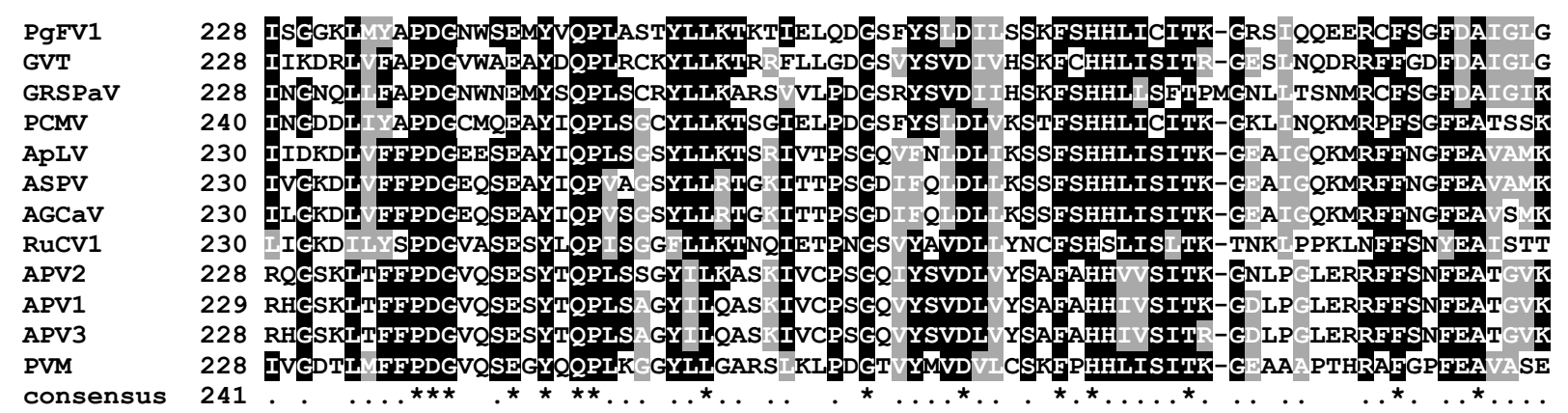

PgFV1

GVT

GRSPaV

PCMV

ApLV

ASPV

AGCaV

RuCV1

APV2

APV1

APV3

PVM

consensus

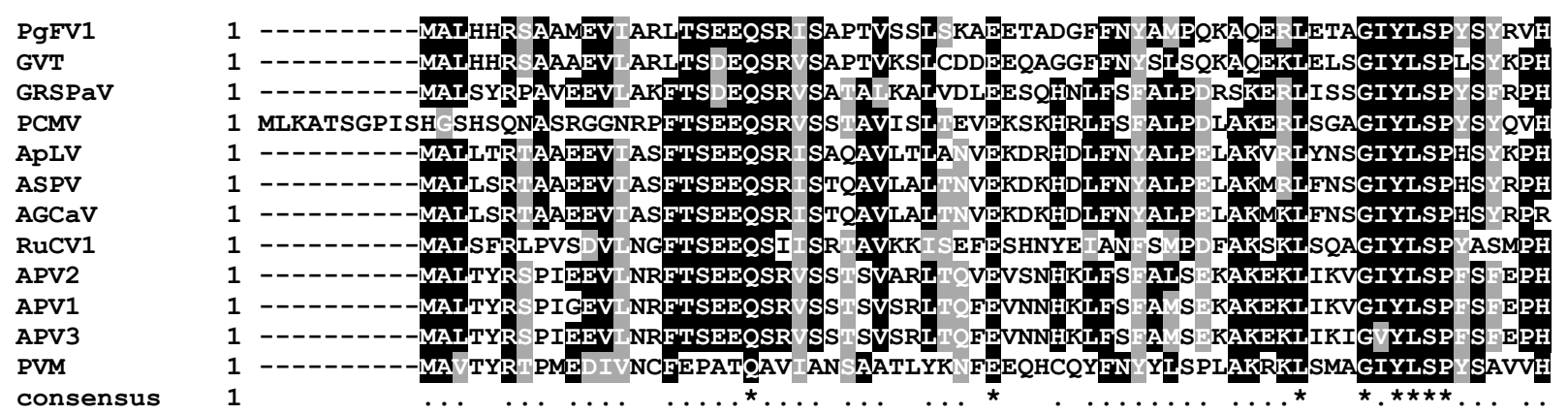

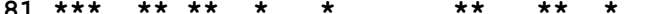


Fig. S1. Continued

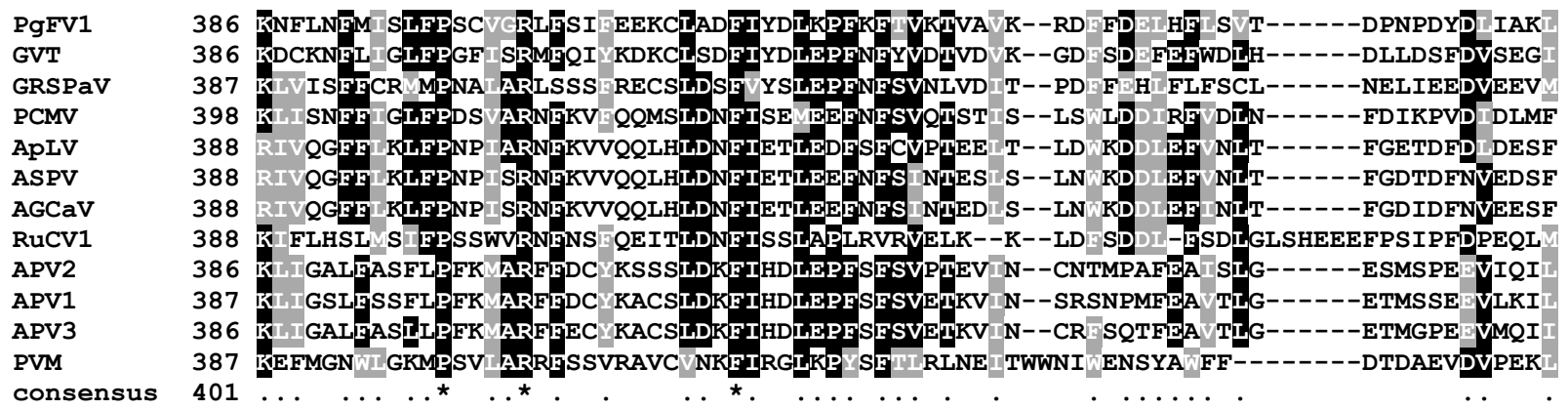

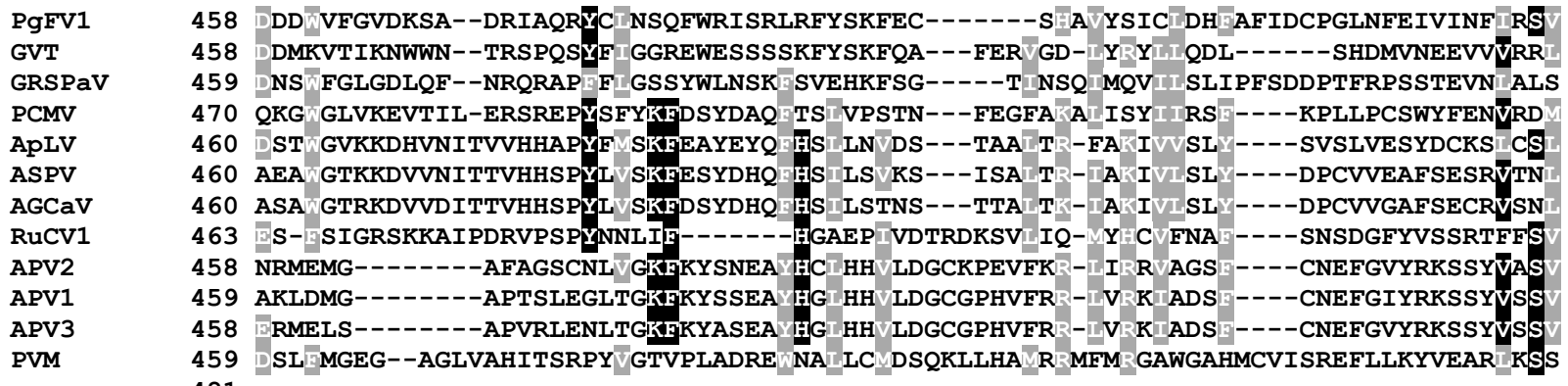
consensus 481

\begin{tabular}{|c|c|c|}
\hline PgFV1 & 529 & ---IKARKL-----DPQLCVINDD---FFDVFSKLSR---KLRDRLNKVDARVDIC \\
\hline GVT & 526 & RRG------TESLA MISCNLDI--TALK TV N---WTLEARKEN TR \\
\hline GRSPaV & 532 & T-----GQSKLFRFLVDDCAMRE V--RSS KVGLFKHIKALTHC NS \\
\hline PCMV & 542 & ------GLGKSV̄STSCFTADLRA FDSSVKP----KLHQPPPLI W \\
\hline ApLV & 532 & -----NLRACFTVVDLWKTFRAILIKEGNR----SKGRMRKK \\
\hline ASPV & 532 & --NLRACFA TDLWRIFEGILLKEKR----AQGKMRKR HF \\
\hline AGCaV & 532 & ---NLRACFA TDLWKTFEGILIECKK----AQGKMRKR YFIG \\
\hline RuCV1 & 530 & ISMCSGRLVKDVY LNIRRKIFFVRSPTSGAQIF \\
\hline APV2 & 525 & $---N L N L D I I G S D L N Q K V V C I V R N F S----S K K S S Q L I Y S T N S$ \\
\hline APV1 & 526 & $---N S N L S F I F G T D L N P M I I G F V R Y A----S R R S S L L I D H D R$ \\
\hline APV3 & 25 & IFGADLNPMVIGFVRY $\mathrm{S}----S K K A S L L I N \mathrm{~S}$ RF \\
\hline PVM & 537 & -GQHKE--KLEAWEVLGLKSSDAL RAMTYLCNARLEPM S \\
\hline consensus & 561 & \\
\hline
\end{tabular}

PGFV1 593 ENGTDRTSOSRYNA

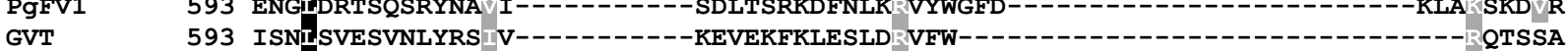
GRSPaV 603 FADLDCEVIKVYQLVT----------SQAILPEALLSLTK VFVRD---- - PCMV $609--D-Y C R--------------A D F R S F K I F K S R$ FIN-------APLV $599--$ GLFVRSLNFDRFIK--------NCQCNLSFHRGRMALH--ASPV AGCaV RuCV1

APV2

APV1

APV3

PVM

consensus

$599--$ GLIARSVSFDQF IK---------GCQRDNSLHNGRMSLR-- - - - - - - - - -

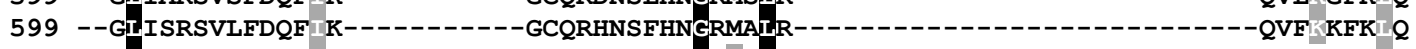
609 ESNLETKVFTSWMK VDEVLLINSSSSLGMRSTLRDSGL RNIWEYNCSTTSYPAPSATESVEKV----- - EEIEEES 595 -AS NCKDLSTRKN I----------LDFEVFGFCA GL RLGSSGVSSVVP PKPVLGGFEFVP-----PGEEA EDDIE 596 -NDLGLVEFRMRKN A--------LEISNFDRNSNL KLGSFQTAPTNSKSNTSSSEGASNHQREQ-RDQCDEATIQ 595 -DQ GLSDFRIQKSIT---------AEVKEFDRKLGLRKLGSFNLSRPYQVQDQLPPLKSVNEANCVSGDIEQGSNPE 608 -KRAVTGVQNLWSNVV--------HEVSTKRHKGMIRLE-641

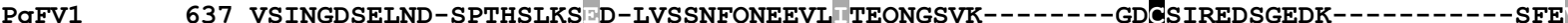
GVT GRSPaV PCMV APLV

ASPV

AGCaV

RuCV1

APV2

APV1

APV3

PVM

631 MEFGGPKFEISEEPVVEVEEQC-APEEVIDVGSKQTSAVIHAES-QATAPSYVDCT------647 RLVSRNELEELAHPANSALE P----QSVDCNAGRVASVSSSQ-QLADTHSLGSVKSSIETANK-----------AFN 638 NHCTSPIFFGLESSSTLSTITD---EVPIPCTPKS TPDALSDS-------NFPTFIHSC-GNLR----------CAK 638 SLLDEYELNSHKKFVEKQDVRT-VEE IEKEQDPHTFENHENSSP------ATVGCSLVPCACSTN-----------CEVQ 638 ALFDVSELSI I HNVEMENAP A-GSTIDAGIKPTSSPLEVVPIE-------NARCNLAPCKCDLN---------CFIQ 638 ALLSESELSVVHMVEIRTVP V-EPT VDEQHLTATPSEVVPIT-------TVGCNVVPCKCNLN---------CFIQ 682 THENVPILKRDVSSFLKIAFNV-PTVQEEVVEVKDVVET GTEE-------EFEAPALEKFGDAGI---------VFGR 658 VKSNTMAKMFDPSPQAVLGI G-PAAGVHEIDPQDQTLSPKAADLEERNGLIFGCVPEPSLMNFSFSSANQGDRLFANI 663 VNFQREIEFCMGSLPEANSFKSFTPC VEAVATSYEVQP EPEP--EANGLVLGCI PDASTPAFTFNSANQKDRLFSSV 663 VCFAMEMEFGRRSPSSGTS ILAPN AAELAVKE VDSTAPER--KHEGLVFGCI PDSSTGAFAFCSANQHENTFAAV consensus 721 
Fig. S1. Continued
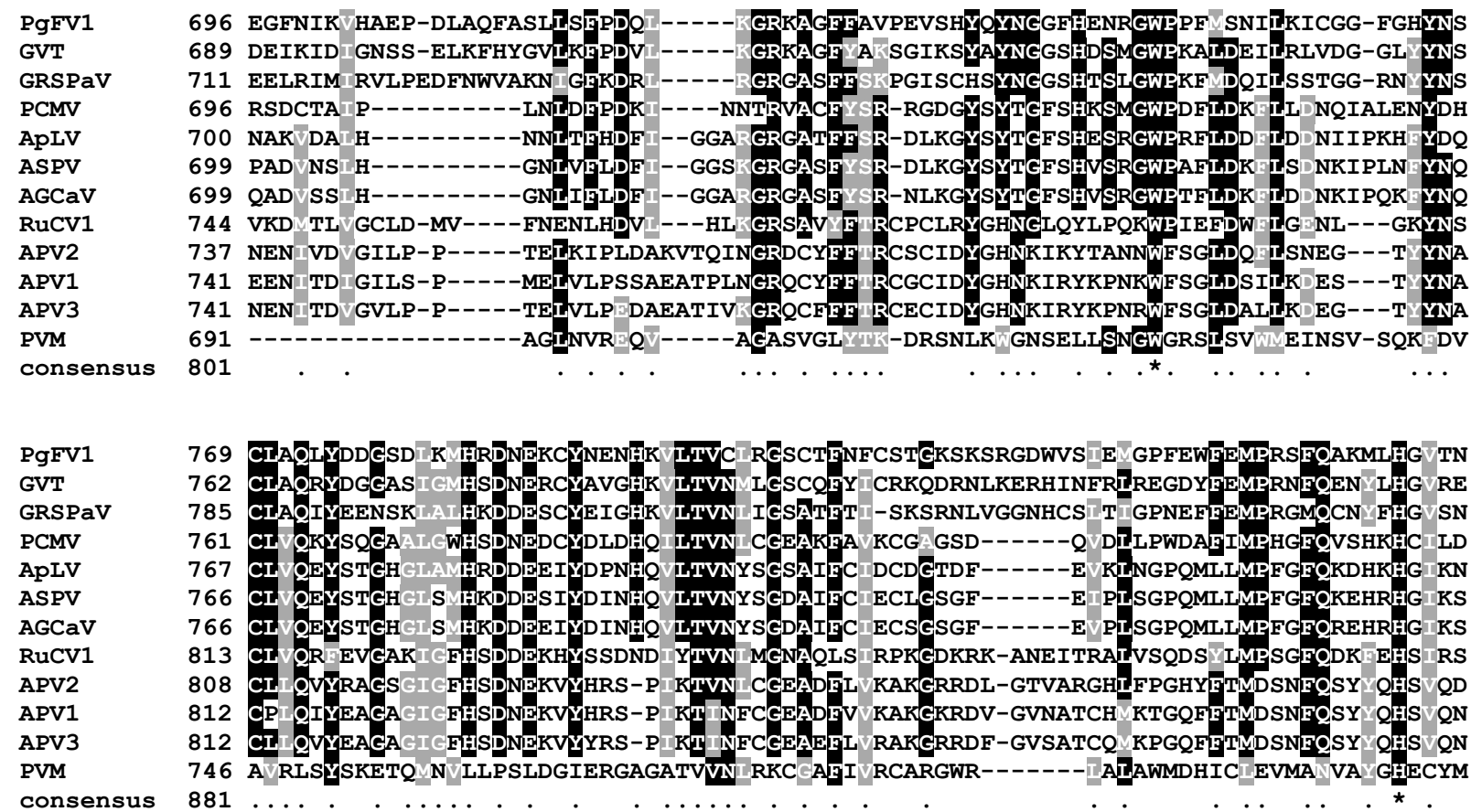

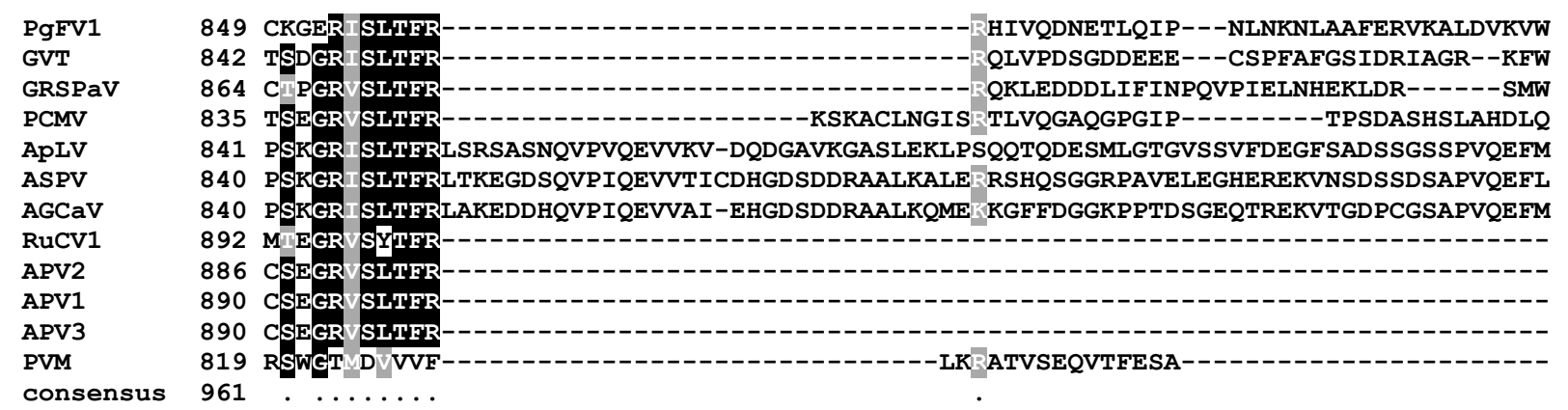

PgFV1 893 -----NLGKKM ADILKTKRSCFISDICACFSCSNFDKFSADLSK SKALGAEGVAAEDRI-ILFDQTAKPEIFRDALSR GVT $884----$ PECSNY $\triangle A$ A IDGSGKGRELD CDCFSCPNHFRHAKNIDGIRKVFSAT GLAAGDRV-LVLNSKSSKA LEKFERI GRSPaV $905----$ QMGLHGIKKSISMNGTSFTSD CSCFSCHNFHKFKDLINN RLALGAQGLGQCDRVVFATTGPGLSK LEMPRSK PCMV 883 VDVDGSVVELIRGK GGKFGKGYQSDICCCNMSWATDEDEPILET RSLSFACGFSNVDRV-LISDVNSITT SSLLEVE APLV 920 IQIDSSLLEYADKS SGSSKDLINCDICLCNS PWLKNEELKFSEA RDLAFAS SFNPTDRFSLAKGVSGVRG NRI ISEI ASPV 920 IQIDSSLLEYA KS S SLSKNVVNCD CLCNSPWLKNEELRFSEA RDLAFAQGLIQLIDF-LCLKVLRCAE NRIISEI AGCaV 919 IQIDSSILEYA KS S SLSKDVLNCD CLCNSPWLKNEELKFSEA RDLAFA SGFNPTDRFSLAKGIEGVRG NRIINEL RuCV1 903 - $997---K V$ HDSLGQ-APV2 897 --------HHVNN T T 2 L-- 901

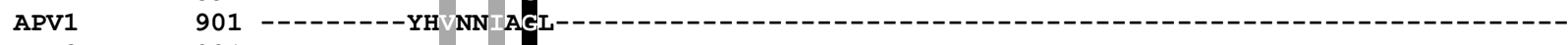

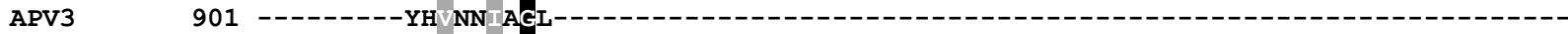
PVM 845 - $1041---Q E$ G GIEGK---

consensus 1041

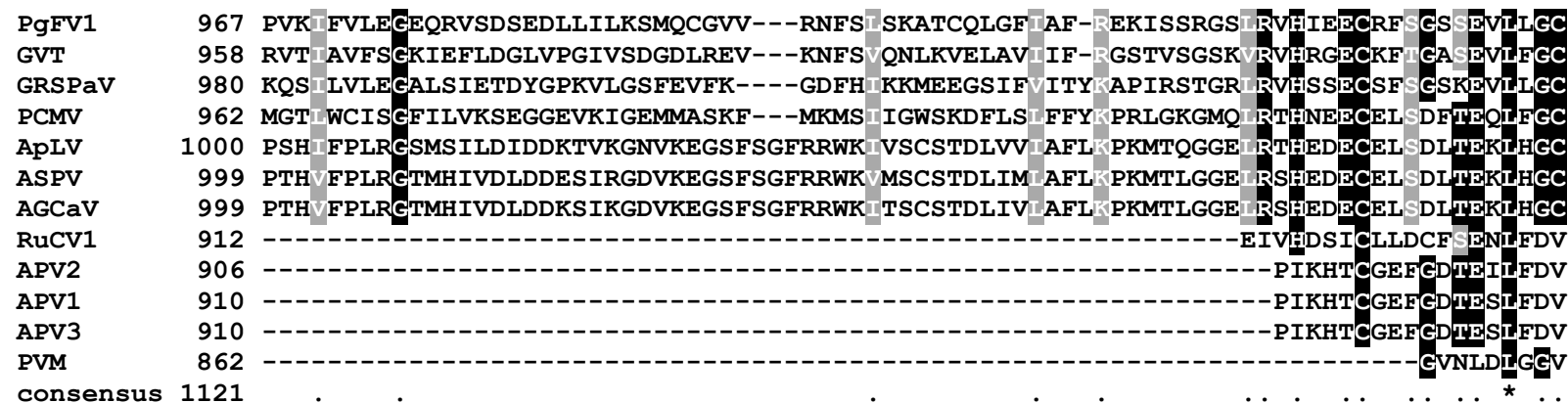


Fig. S1. Continued

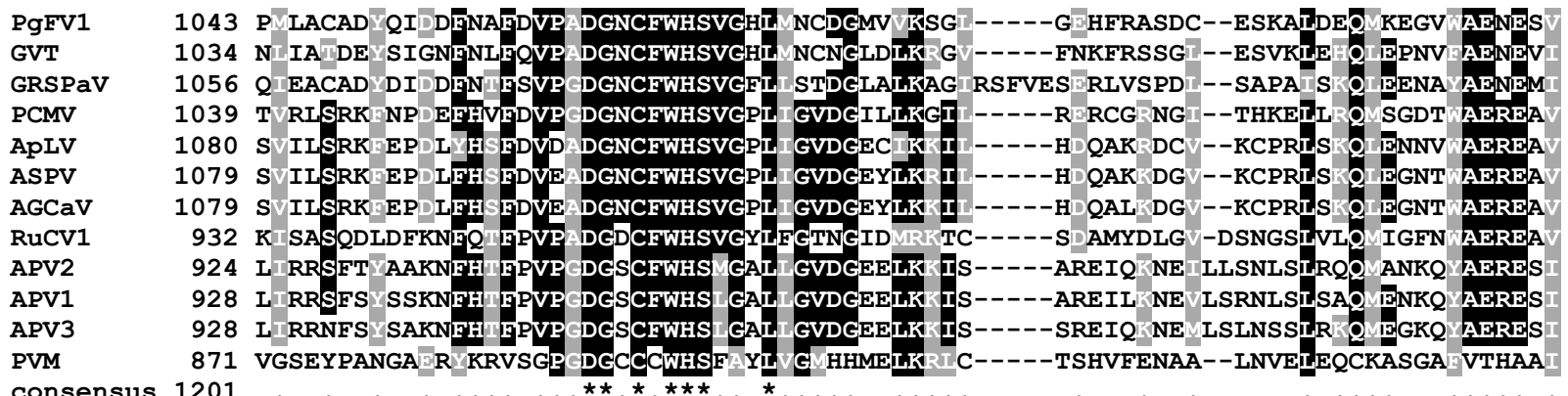
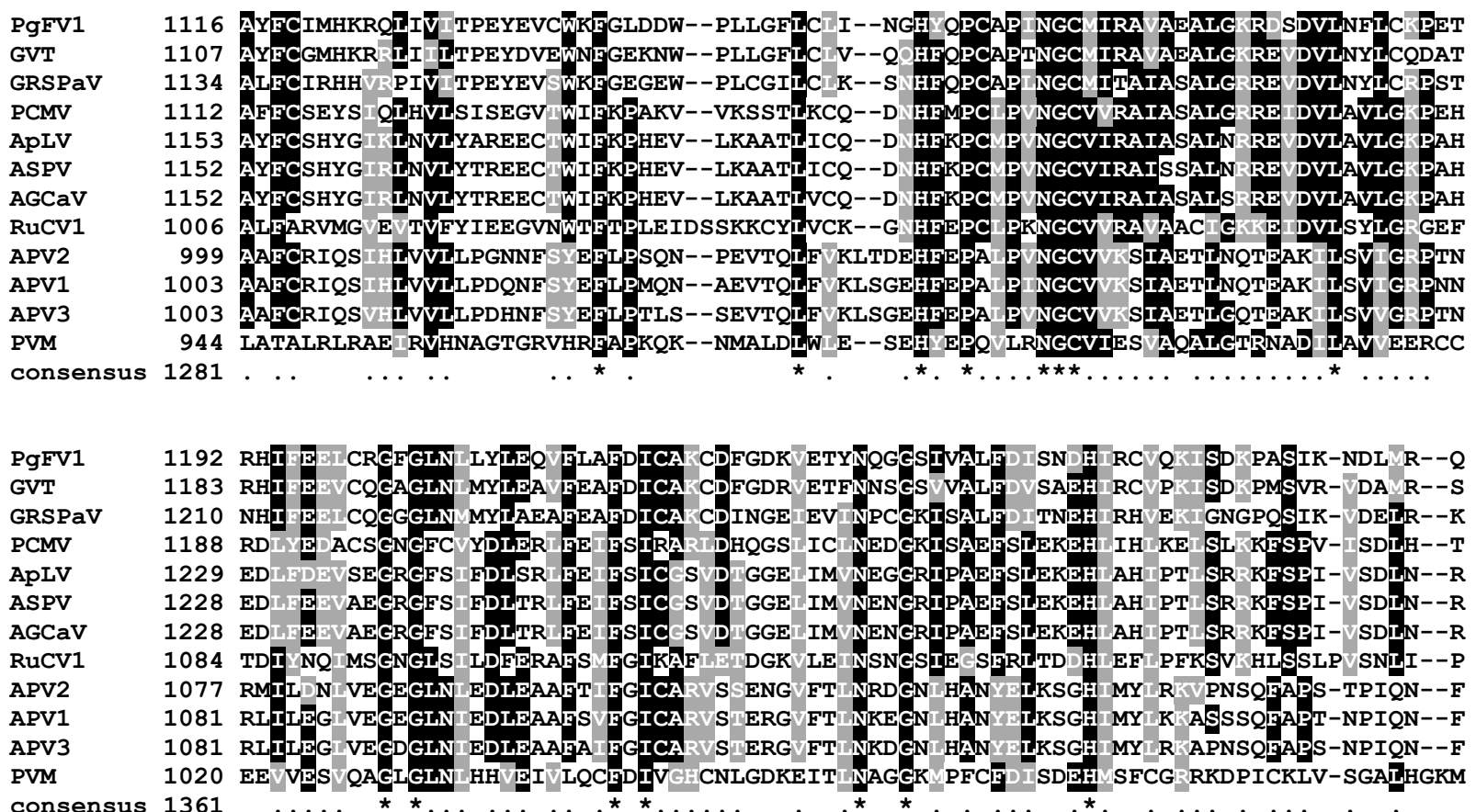

consensus 1361

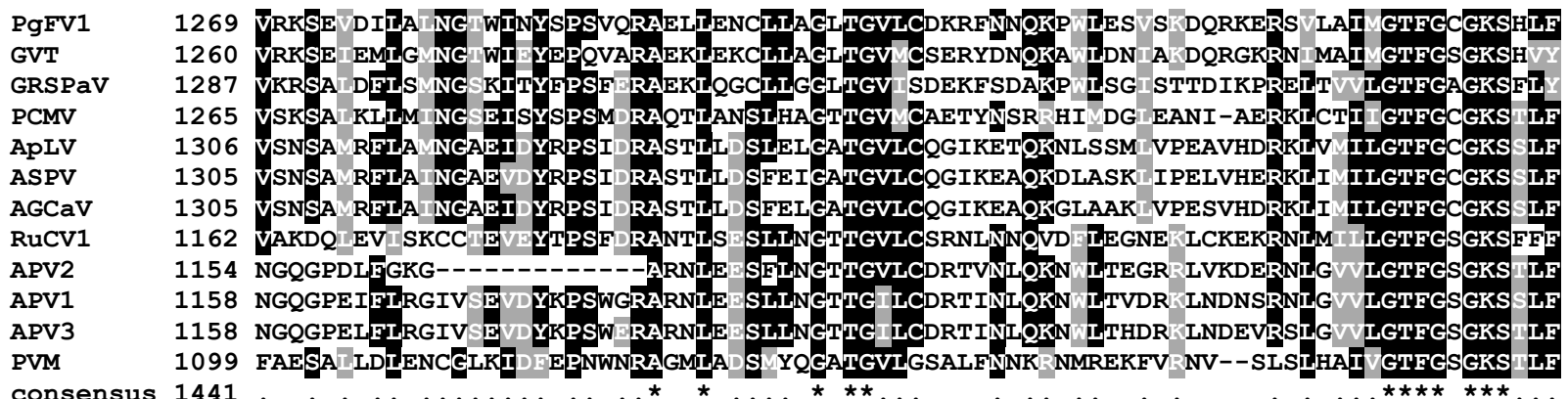

consensus 1441

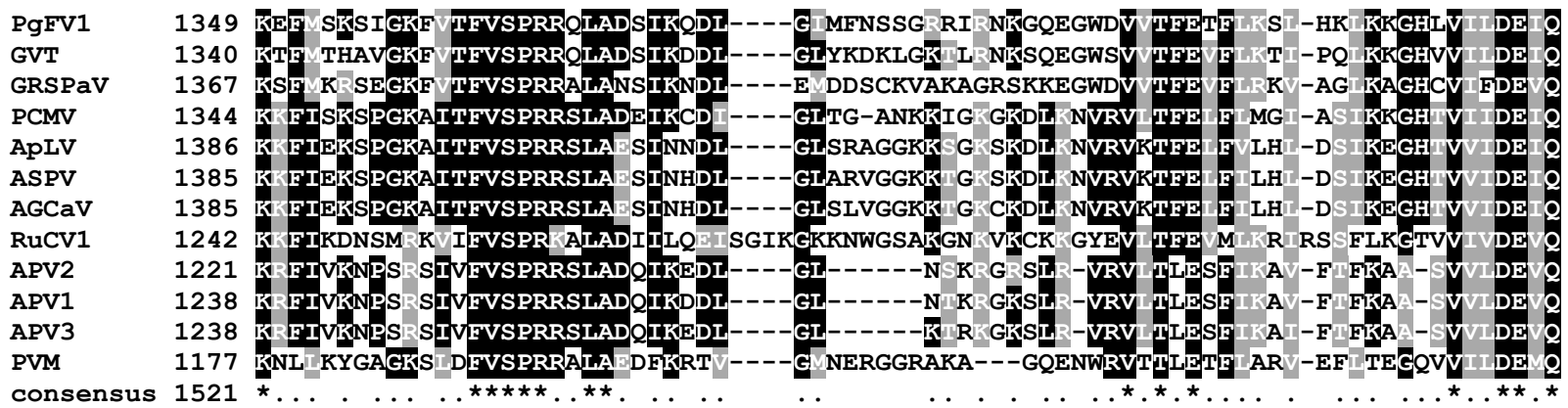


Fig. S1. Continued

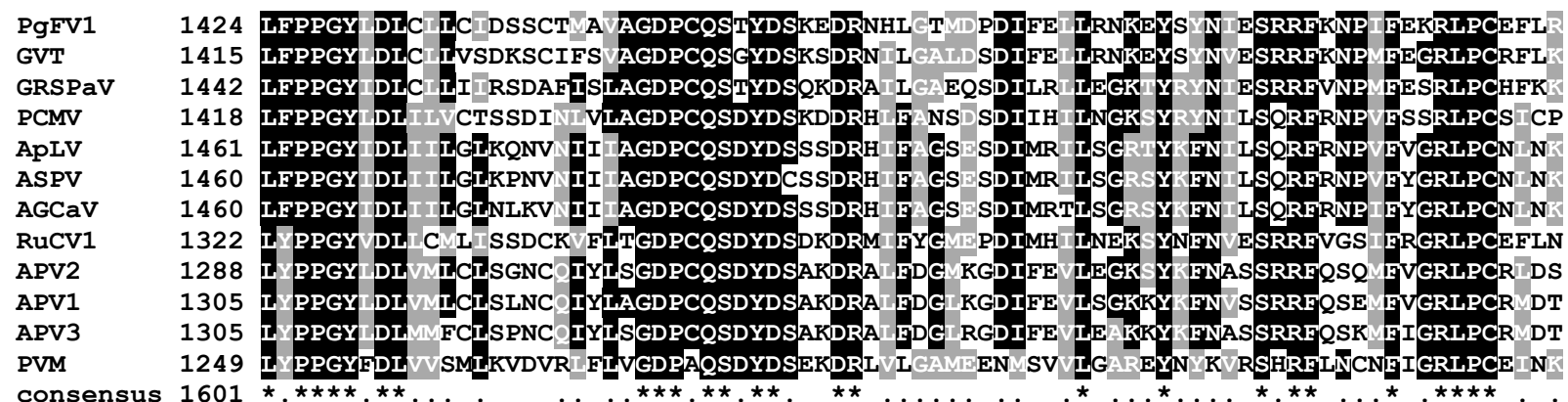

PgFV1 1504 GS IHLKIF FAINS ADFIYAKKEKP-DVYLVSSFEEK IVSSHAGSS RCLTFGESTGLNF QGVILI Y SIHFDD GVT 1495 GS HEKHQDVV KS EDLVFGEKFKI-DAFLVSSFEEK IVWSHFGSA TCLTFGESTGLNE E VV II Y SIQTDDN GRSPaV 1522 GS TAAFADYAI HN HDFLLARSKGPLDAVLVSSFEEKKIVQSYFGMKLTLTFGESTGLNFKNGGILI H SFHTDDR PCMV 1498 KR TMDEF YTLNDSITQFELAGGKNF-PVVLVSSFEEKKVVAAHLGLK KCLTFGESTGLNE QK GAIFVS YESSLTS

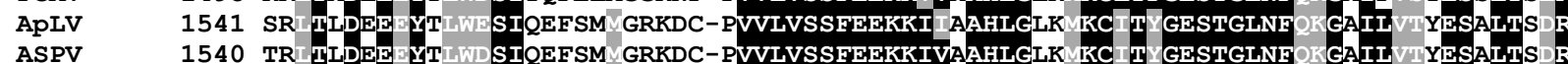

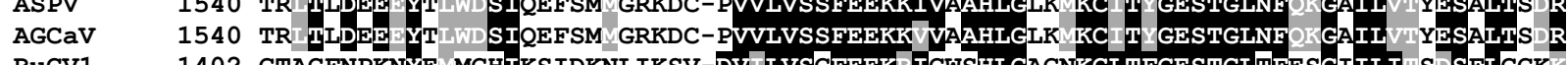
RuCV1 1402 GTACFNPKNYE MGHIKSIDKNLIKSV-DV LVSGFEEKRICWSHLGAGNKCLTFGESTGLTFESGI ILI S SFLCGK APV2 1368 KD VGD-FDFHL SIEAAAEV SNTEY-DVVLVSSFEEKKI WAHLGRD EVLTFGESTGLTFVRIILI HESTLTG

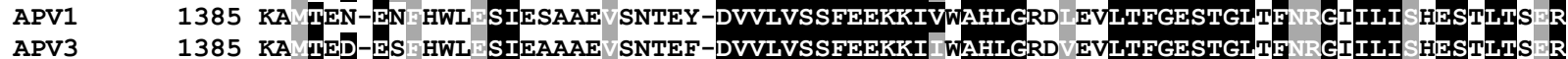

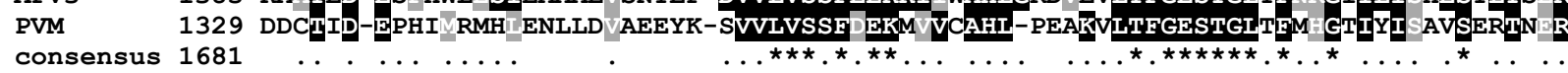
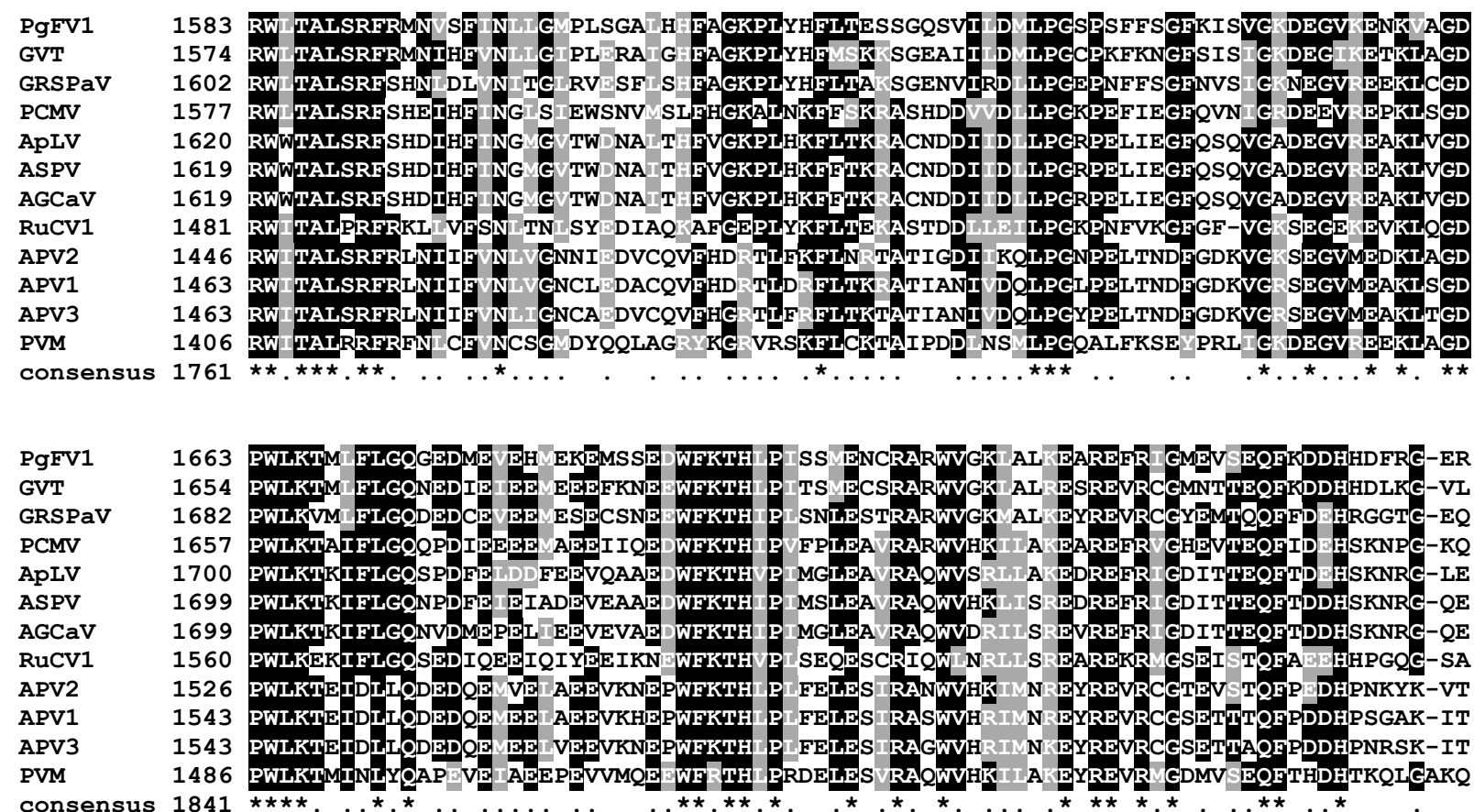

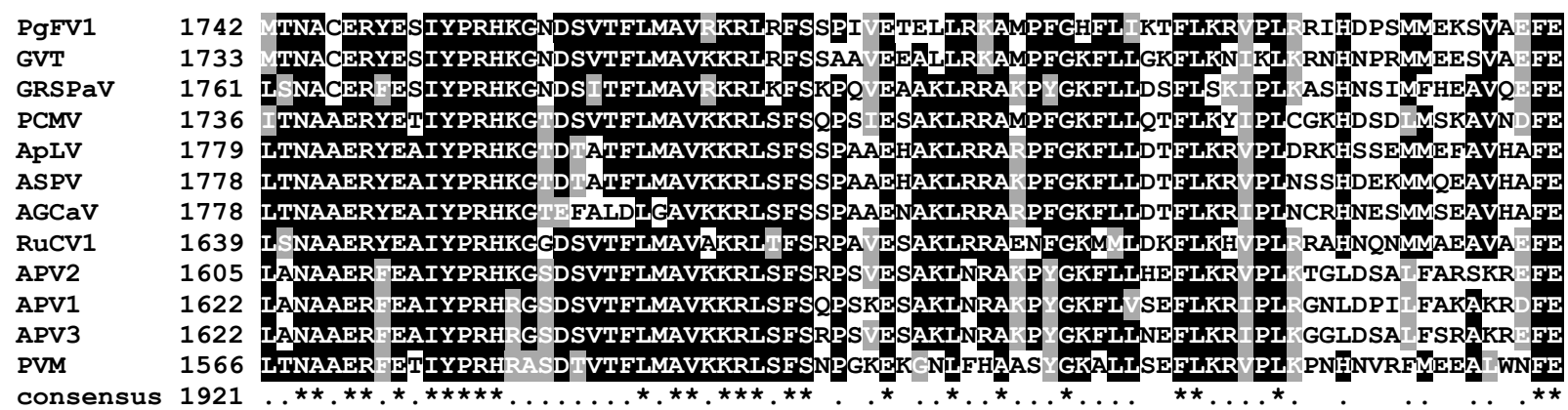


Fig. S1. Continued
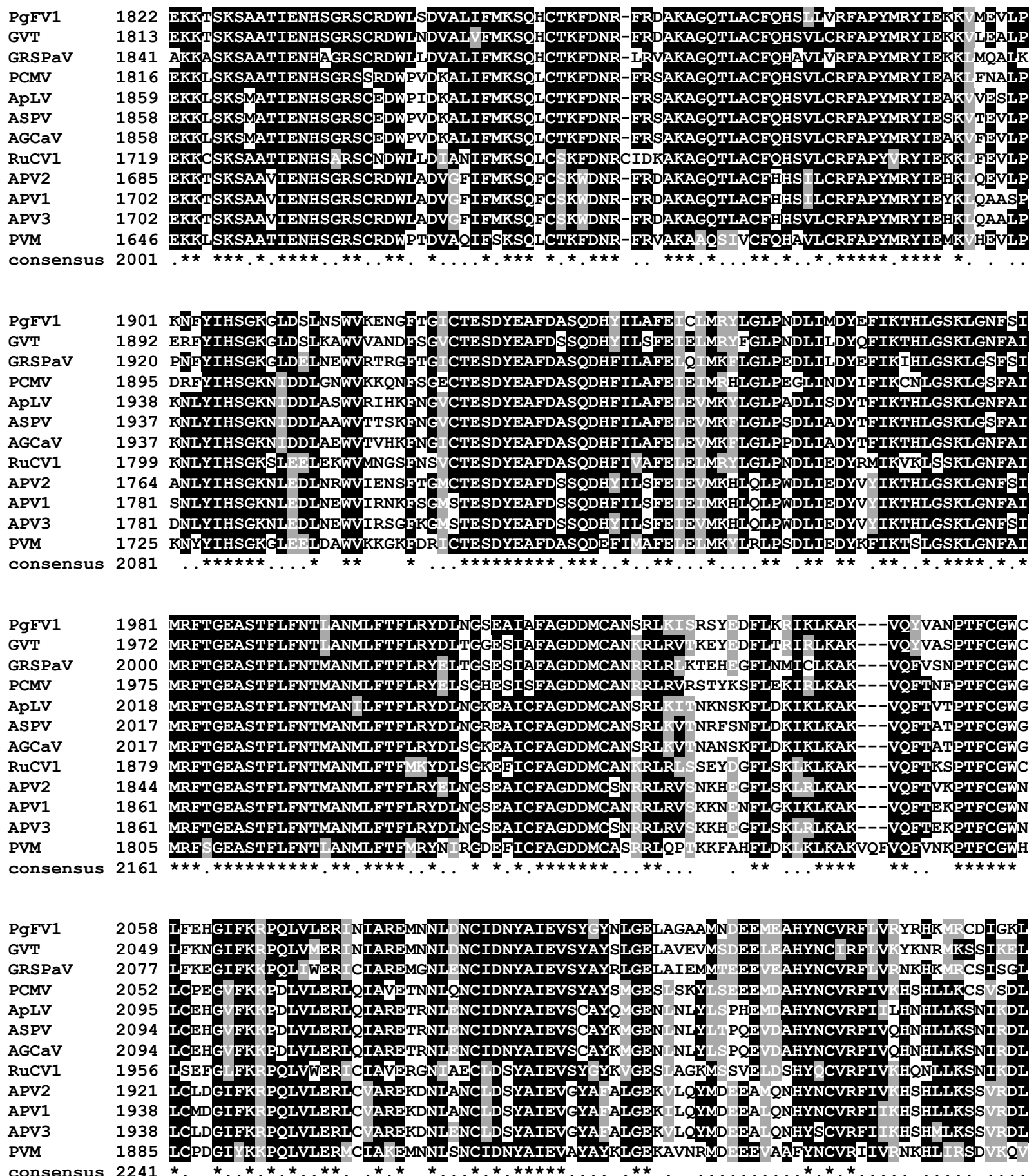

\begin{tabular}{|c|c|c|}
\hline PgFV1 & 2138 & --------- \\
\hline GVT & 2129 & \\
\hline GRSPaV & 2157 & AID - - \\
\hline PCMV & 2132 & II------ \\
\hline ApLV & 2175 & RGEPTIVTL \\
\hline ASPV & 2174 & GESLPASS \\
\hline AGCaV & 2174 & GEAAVGIK \\
\hline RuCV1 & 2036 & D------- \\
\hline APV2 & 2001 & LQNM----- \\
\hline APV1 & 2018 & LSGM----- \\
\hline APV3 & 2018 & FLGSM----- \\
\hline PVM & 1965 & VL--- \\
\hline
\end{tabular}


Fig. S2. Multiple sequence alignment of TGB1 protein sequences of PgFV1 and related viruses

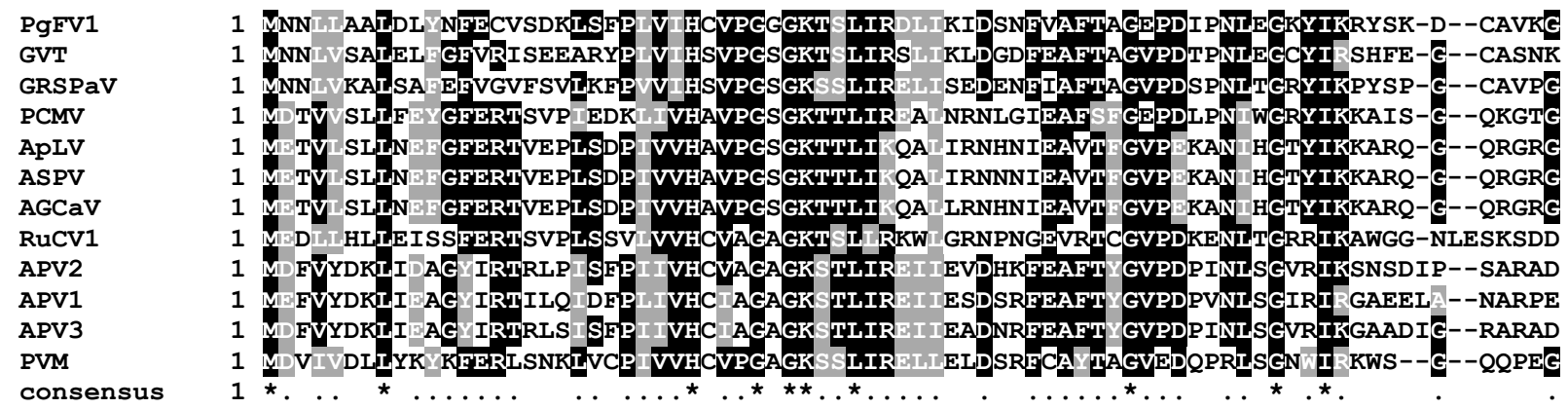

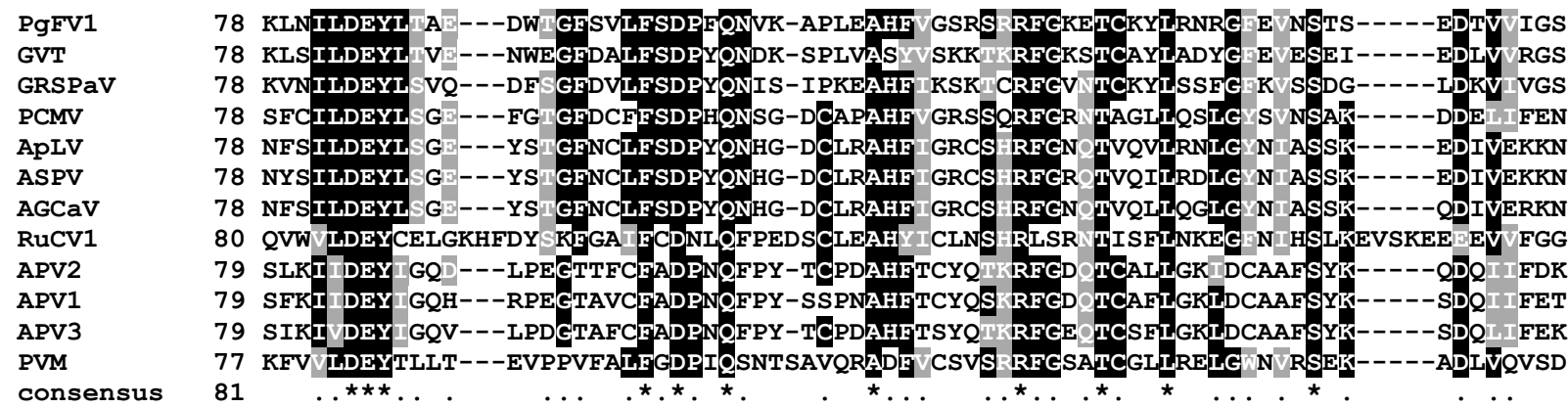

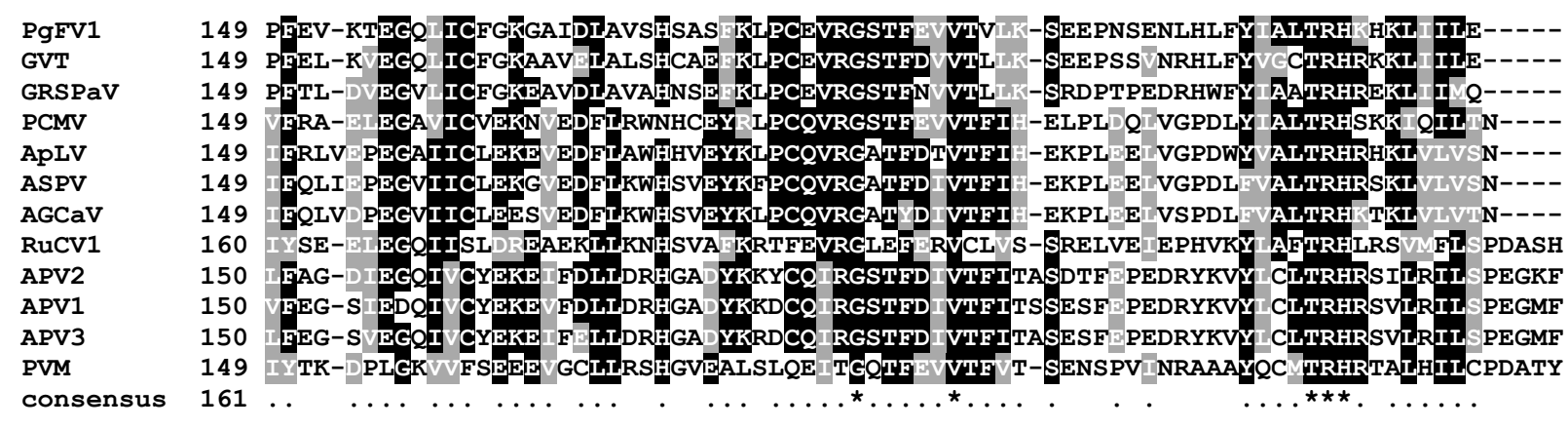

\begin{tabular}{|c|c|c|}
\hline & \\
\hline & 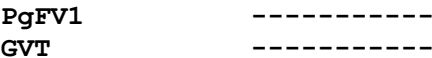 \\
\hline \multicolumn{2}{|l|}{ GRSPaV } & \multirow{2}{*}{ 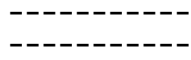 } \\
\hline \multicolumn{2}{|l|}{ PCMV } & \\
\hline \multicolumn{2}{|l|}{ ApLV } & -- \\
\hline \multicolumn{2}{|l|}{ ASPV } & ---- \\
\hline \multicolumn{2}{|l|}{ AGCaV } & ---------- \\
\hline RuCV1 & 238 & TS--------- \\
\hline APV2 & 229 & LREDAKFDTTT \\
\hline APV1 & 229 & LRDNAKFDATS \\
\hline \multirow{3}{*}{$\begin{array}{l}\text { APV3 } \\
\text { PVM } \\
\text { consensus }\end{array}$} & 229 & LRDNAKFDATS \\
\hline & 227 & \multirow[t]{2}{*}{ TAA------ } \\
\hline & 241 & \\
\hline
\end{tabular}


Fig. S3. Multiple sequence alignment of TGB2 protein sequences of PgFV1 and related viruses

Two predicted transmembrane domains of PgFV1 TGB2 protein are marked by number signs (\#) at the top.

PgFV1
GVT
GRSPaV
PCMV
ApLV
ASPV
AGCaV
RuCV1
APV2
APV1
APV3
PVM
consensus
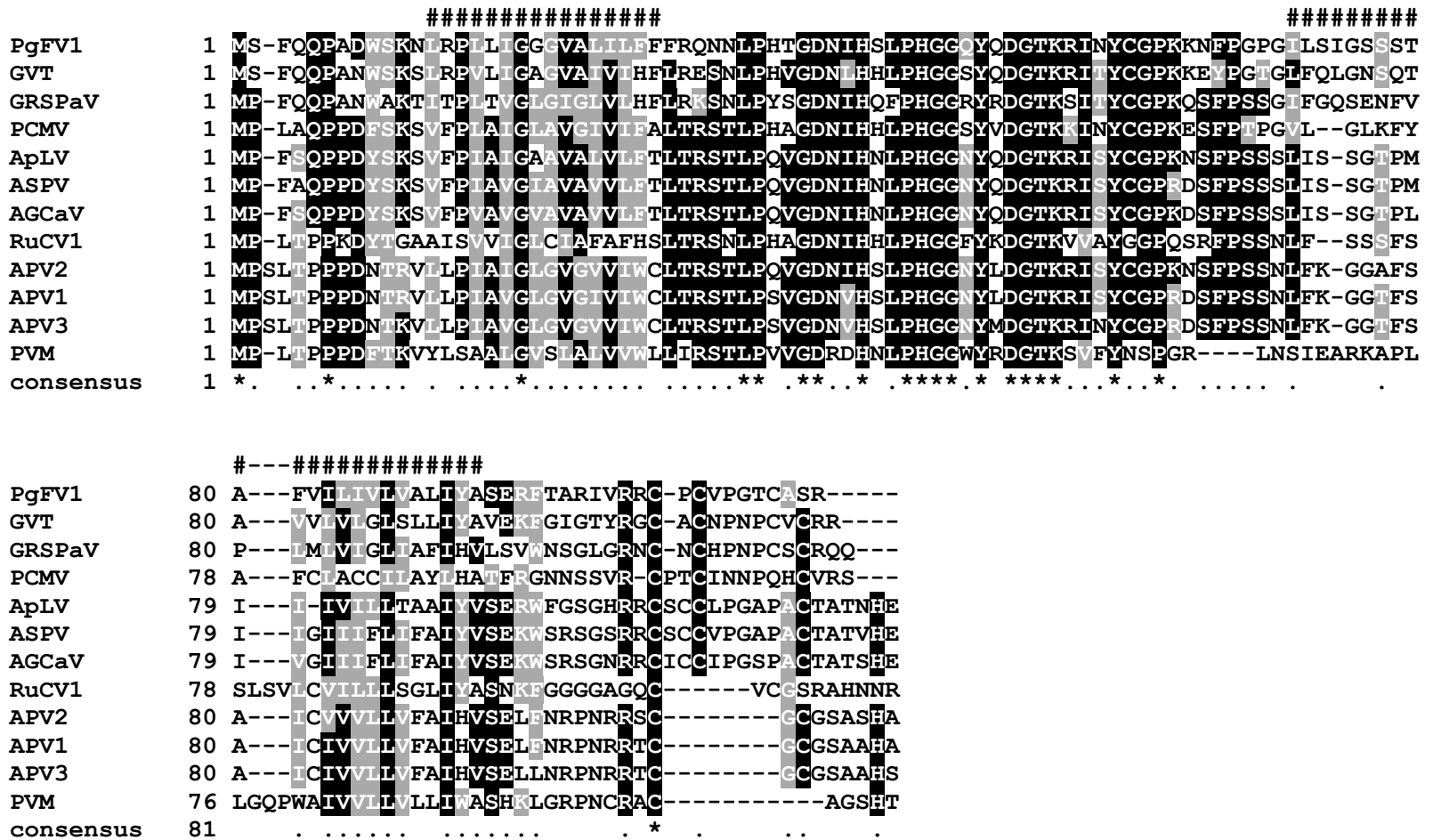

consensus

Fig. S4. Multiple sequence alignment of TGB3 protein sequences of PgFV1 and related viruses A predicted transmembrane domain of PgFV1 TGB3 protein is marked by number signs (\#) at the top.

\begin{tabular}{|c|c|c|}
\hline PgFV1 & 1 & $-\mathrm{MLQKD} I$ \\
\hline GVT & 1 & -MQWRS \\
\hline GRSPaV & 1 & MYCLFG \\
\hline PCMV & 1 & -MQPLE \\
\hline ApLV & 1 & MYPRGG \\
\hline ASPV & 1 & MFPRSG \\
\hline AGCaV & 1 & MFLKSG \\
\hline RuCV1 & 1 & - --MLQ \\
\hline APV2 & 1 & - -MFQSYI \\
\hline APV1 & 1 & --MYQSSYL \\
\hline APV3 & 1 & --MYQSYI \\
\hline PVM & 1 & MIVYVLV \\
\hline consensus & 1 & \\
\hline PgFV1 & 73 & I IEERC- \\
\hline GVT & 73 & -LEGNCS \\
\hline GRSPaV & 75 & EIDYHC- \\
\hline PCMV & & ------- \\
\hline ApLV & & ------- \\
\hline ASPV & & ------- \\
\hline AGCaV & & ------- \\
\hline RuCV1 & & ------- \\
\hline APV2 & & ------- \\
\hline APV1 & & ------- \\
\hline APV3 & & ------- \\
\hline PVM & & ---- \\
\hline
\end{tabular}

\#\#\#\#\#\#\#\#\#\#\#\#\#\#---\#\#\#\#\# 
Fig. S5. Multiple sequence alignment of coat proteins of PgFV1 and related viruses

PgFV1

GVT

GRSPaV

PCMV

ApLV

ASPV

AGCaV

RuCV1

APV2

APV1

APV3

PVM

consensus
1

1

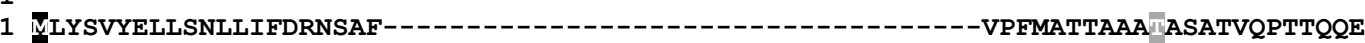

1 MATSGQDTTSANPAVTRNEETPVVTEVQATNAVATTPEVVPVATAPLPASTQPTATTSSFEVSFTPA SISATPMTFPEP

1 MTSNGSQPQASTPMVSAEEPAAAAS---

1 MASNGVSSQSSTPMVSIDENPLVTS--------------SPNPSVVAP------LPVSMPVVAS APEVTFPAISEA

1 MTTSQSTATADVETSKVETSPPPVV-----------TSEPVLQQ-----VVFSDTSNAATPPPPVTTKTST

1 MTTSQSTATADVETSKVETSPPPVV-- 1 MSVSSAAVVSTVSSTSSEAVPVTSS---

1 MTTSVSAATTDVMSTSVETAATIAP--------------ANEPVIQQ-------VIYPKSTAVA SVAPVMTHTAQR

1 -

PgFV1 1 - 1 -------------MEK PEQLQSEKES $\triangle$ ELARLSEERAAEKKAANDKKLELQH-----NRNAHRSGSSSRSAP

GVT

GRSPaV

PCMV

ApLV

ASPV

AGCaV

RuCV1

APV2

APV1

APV3

PVM

consensus

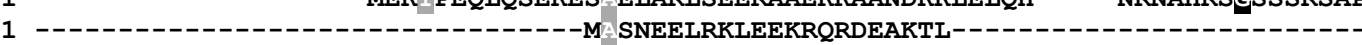

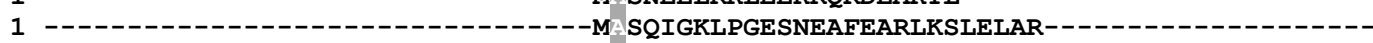

45 VTAGLQSTTS--STF-PTVTPVE PARVATTRSDPVTSGYSLGNVTAALTRPTGSLPITVGLG--ALNLGDGGAVAVGGV

81 VVSQLVPFPPLVATGQSSVQTTAVPDTSRLQQMA ANRGFSEG------LRVHPLPITPA-----SSNPFTTGNIFTSSV

64 VISQVQSLAPIVSGFDPNLHGRL NEQMRQAQNE AMQGYEEGSRRNPRLPSSTTAHNDYASM- - NSNPFETGTAYGGAP

58 VISQVQSVAPMVNGFDPSLHGRL NEQHRAAQEE ARLGFQSGIQQRRQ PVTSAYAITS-------NPFETGNAYSVAP

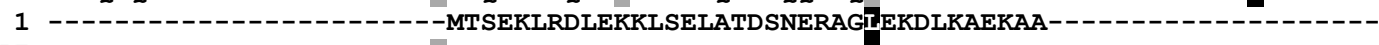

57 AATKGVERSWFGLPSKTTGLGTLSATATSTSPLLSASGRASQLDENLKKLKAKDESFFVL---- -NSEVEDLEAKASGKV

57 VENPFKPRTSFSLPSLTAGLGTLSATATSSAPAATSEARTSSLESWKEKLKNKDEEPRRV-----LSEPESLGSFEAGAG

57 VEDPFKTRTSFSLPSLTSNLGTL STATAAASSTTSDVKSSTFENWREKLKTKDDLNFPRTTGVEHLGSFEAGEGSRGGS

16 TSQERREARPLPTAADFEGKDTSENTDGRAADAD EMSLERRLDSLREFLRERRGAIRVT-- E

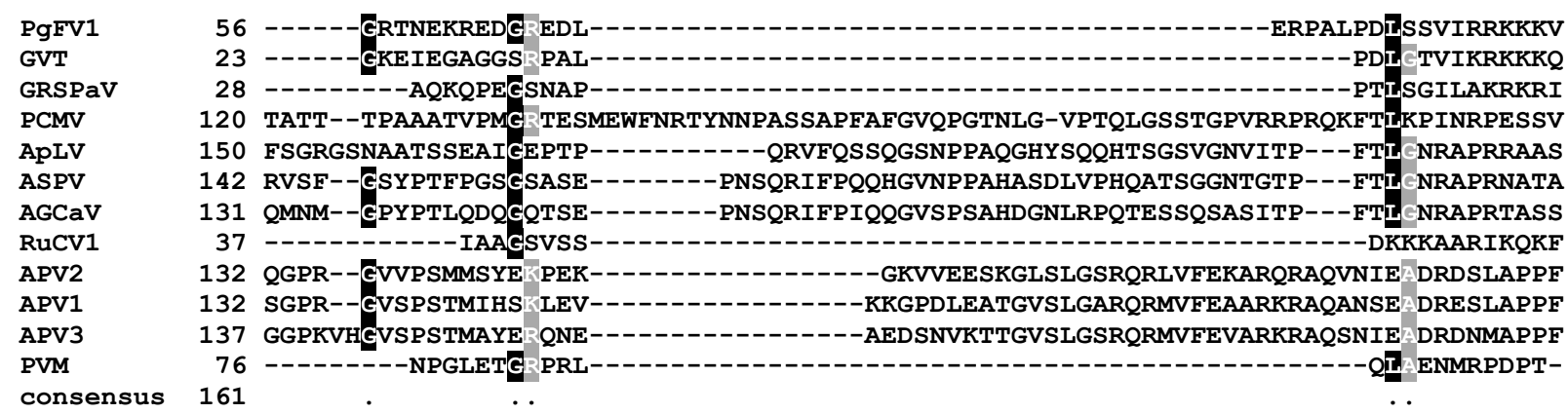

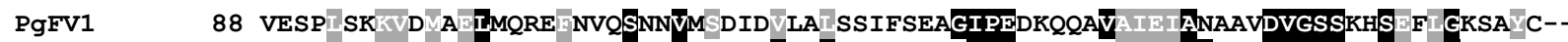
GVT 50 IENA SAKVN K LMERE GLQSNNVMNNNDILAISS I FTEAKI PEDLQQHTAIDVARMAVDVGSSKHS F GKSVVC- GRSPAV 52 IENA SKTVD R VLKHETVVISPNVMDEGAIDE IRAFGESGIAESVQFDV IDIARHCSDVGSSQRSTLIGKSP C- PCMV $\quad 197$ VGSG SKR S RDLAAIDYKPQAGSVASEEKISQIGLEFTKIG SSDQLTEV GVF IARHCADVGSSNQSRLIGTFPGS-APLV 216 SIGGTRRR DSVGLKSIMYEPQAGVVA DAK RAIGRAITEMGIREDQLTEV GV Y ARHCADVGASDKSTLIGTFPGS-209 TTG $\begin{array}{lll}\text { ASPV } & 209 & \text { NTGG RRR DSVGLKNIRYEPQAGVVA NQKIRA GVAL GMGI PEHQLTEV GVY ARHCADVGASDKSAL GTFPGS-- } \\ \text { AGCaV } & 198 \text { ISGG RRR DSVGLKSIIYEPQAGVVASDQKIRAIGMALIGMGIGHQTEVGY ARHCADVGASDKSTLIGTFPGS-- }\end{array}$ RuCV1 57 SGSSITSIPTNKMLREIKISTEVRNVC LSNAELIAAEFVELGIPEDKLAEA WDIALHCADVGSSEL LAGTCT A-P APV2 192 ASADPFSRPK QDVQRFYFPSSPDIS AEEIEHIRSDIVRAGVPESTLTFSMWDIARYCADAGSSAS FI GTSS S-G APV1 193 ASGDPFSRPK QDVQRFSYEPSSPDVA AENIEYIRADIVRAG PTKD TFAMW IARYCADAGSSES FV GTSS G-G APV3 200 ASSDPFSRPK QDVQRFSYEPSSPDVA AENIEYIRADLVRAG PKKDLTFAMW IARYCADAGSSES IIF GTSS G-G

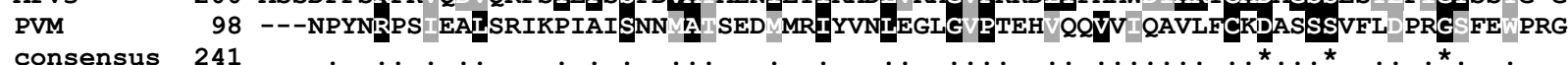

consensus

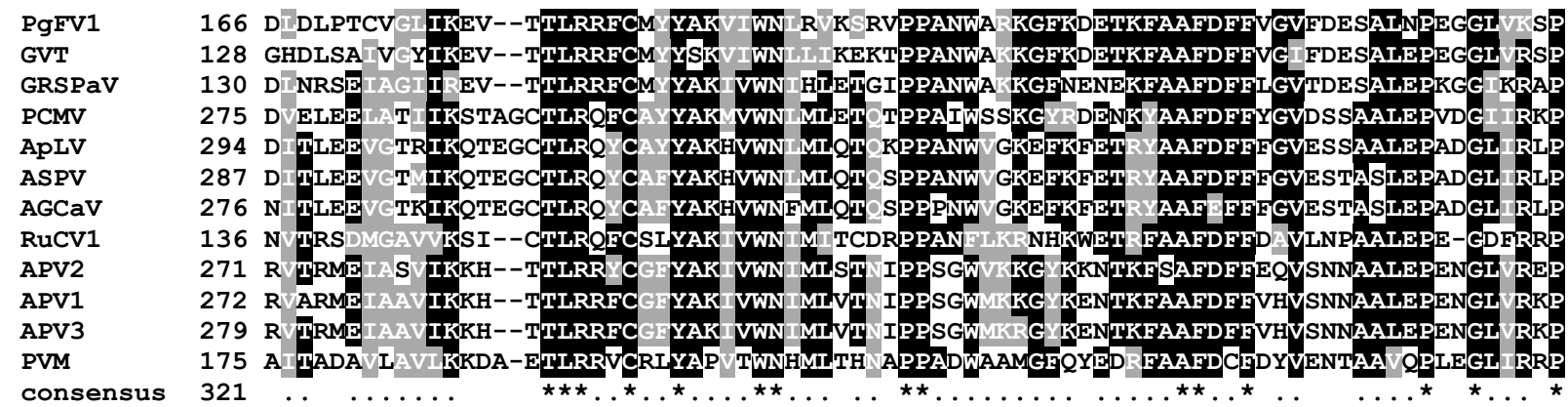


Fig. S5. Continued

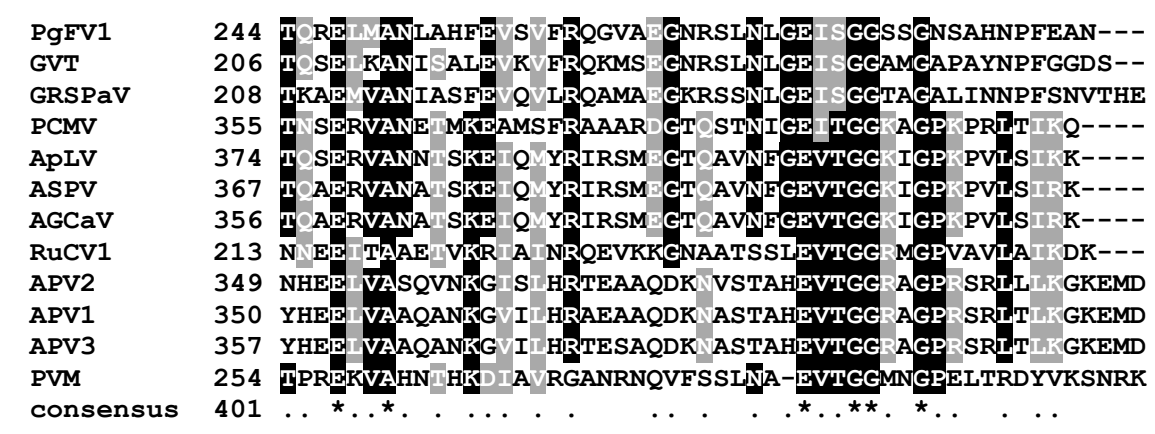

